\title{
Archaeological Reconnaissance and Survey of the Northeast Lakeview College Campus, Live Oak, Bexar County, Texas
}

Kristi M. Ulrich

Follow this and additional works at: https://scholarworks.sfasu.edu/ita

Part of the American Material Culture Commons, Archaeological Anthropology Commons, Environmental Studies Commons, Other American Studies Commons, Other Arts and Humanities Commons, Other History of Art, Architecture, and Archaeology Commons, and the United States History Commons

Tell us how this article helped you.

This Article is brought to you for free and open access by the Center for Regional Heritage Research at SFA ScholarWorks. It has been accepted for inclusion in Index of Texas Archaeology: Open Access Gray Literature from the Lone Star State by an authorized editor of SFA ScholarWorks. For more information, please contact cdsscholarworks@sfasu.edu. 


\section{Archaeological Reconnaissance and Survey of the Northeast Lakeview College Campus, Live Oak, Bexar County, Texas}

\section{Creative Commons License}

\section{(c) (1) (8)}

This work is licensed under a Creative Commons Attribution-NonCommercial 4.0 International License 


\section{A trchaeological Reconnaissance and Survey of the Nort heast Lalkeview College Campurs, Live Oak, Bexar County, Texas}

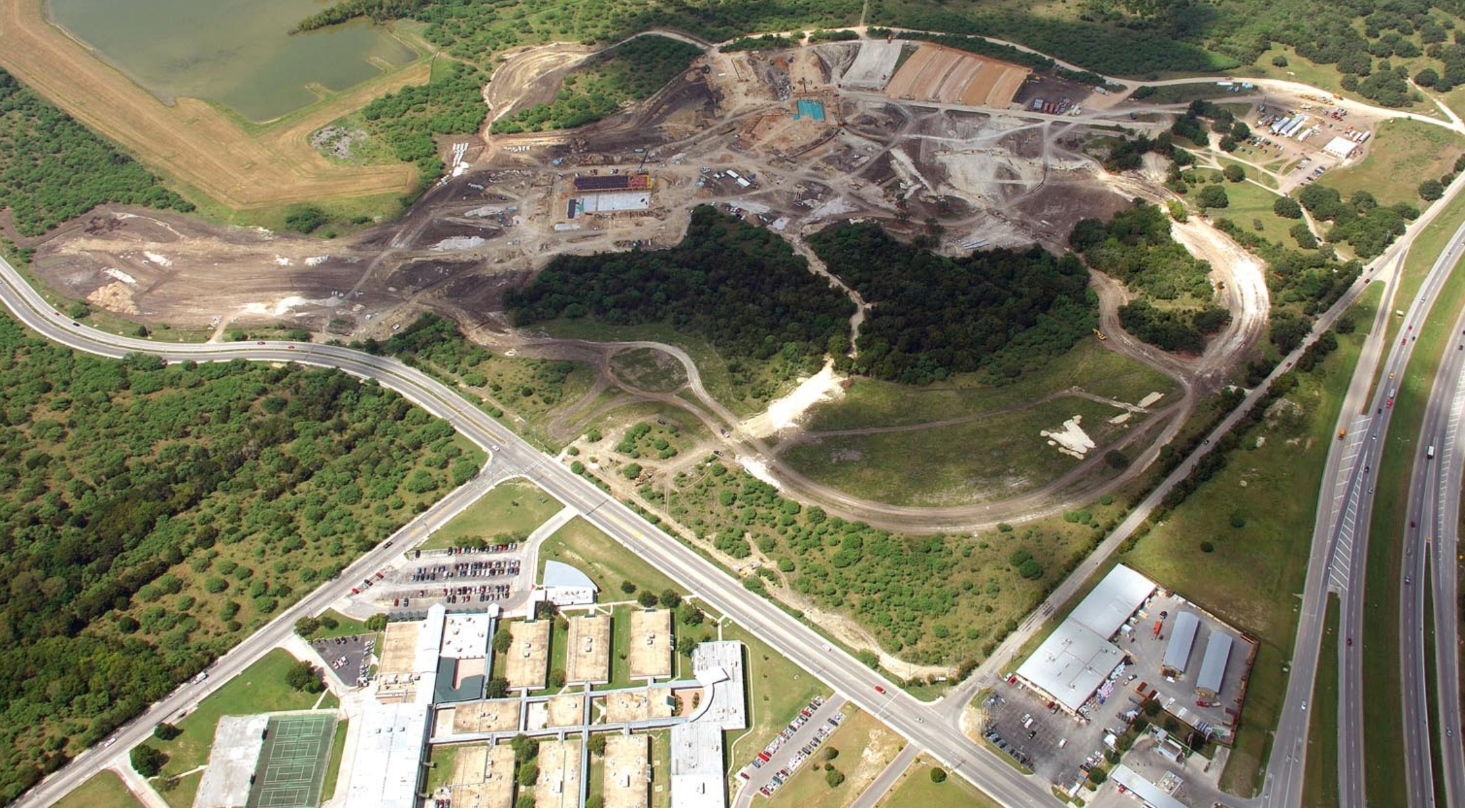

by

Kristi M. Ulrich

with a contribution by

Antonia L. Figueroa

Texas Antiquities Permit No. 4701

Prepared for:

Ford, Powell, and Carson, Inc. 1138 East Commerce St. San Antonio, Texas 78205

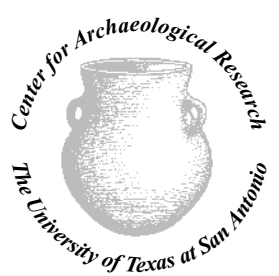

(C)2008
Prepared by:

Center for Archaeological Research The University of Texas at San Antonio Archaeological Report, No. 383 


\title{
Archaeological Reconnaissance and Survey of the Northeast Lakeview College Campus, Live Oak, Bexar County, Texas
}

\author{
by
}

Kristi M. Ulrich

with a contribution by

Antonia L. Figueroa

Texas Antiquities Committee Permit No. 4701

\section{Principal Investigator \\ Cynthia M. Munoz}

Prepared for:

Ford, Powell, and Carson, Inc. 1138 East Commerce St. San Antonio, Texas 78205
Prepared by:

Center for Archaeological Research The University of Texas at San Antonio Archaeological Report, No. 383 



\begin{abstract}
:
Starting in October of 2008, the Center for Archaeological Research carried out a 100 percent archaeological survey of the proposed Northeast Lakeview College campus in the City of Live Oak in northeast Bexar County, Texas. A total of 102 shovel tests were excavated within the project area. Site 41BX15 was revisited to determine the condition of the site. Three new sites were identified during the course of the survey. 41BX1758 is a prehistoric site of unknown temporal affiliation consisting of debitage, burned rock and a biface. 41BX1759 is a prehistoric site of unknown temporal affiliation consisting of a retouched flake, debitage and burned rock. 41BX1760 is a scatter of historic material in the vicinity of the Kruse Family farmhouse. The house was razed at an unknown date and the cellar filled in. All lack research potential and therefore the CAR recommends that none warrant nomination to the National Register of Historic Places or formal designation as State Archeological Landmarks.
\end{abstract}

The archaeological investigation was conducted under Texas Antiquities Permit No. 4701, with Cynthia M. Munoz serving as Principal Investigator. All artifacts collected and project associated documents are permanently curated at the Center for Archaeological Research. 


\section{Table of Contents:}

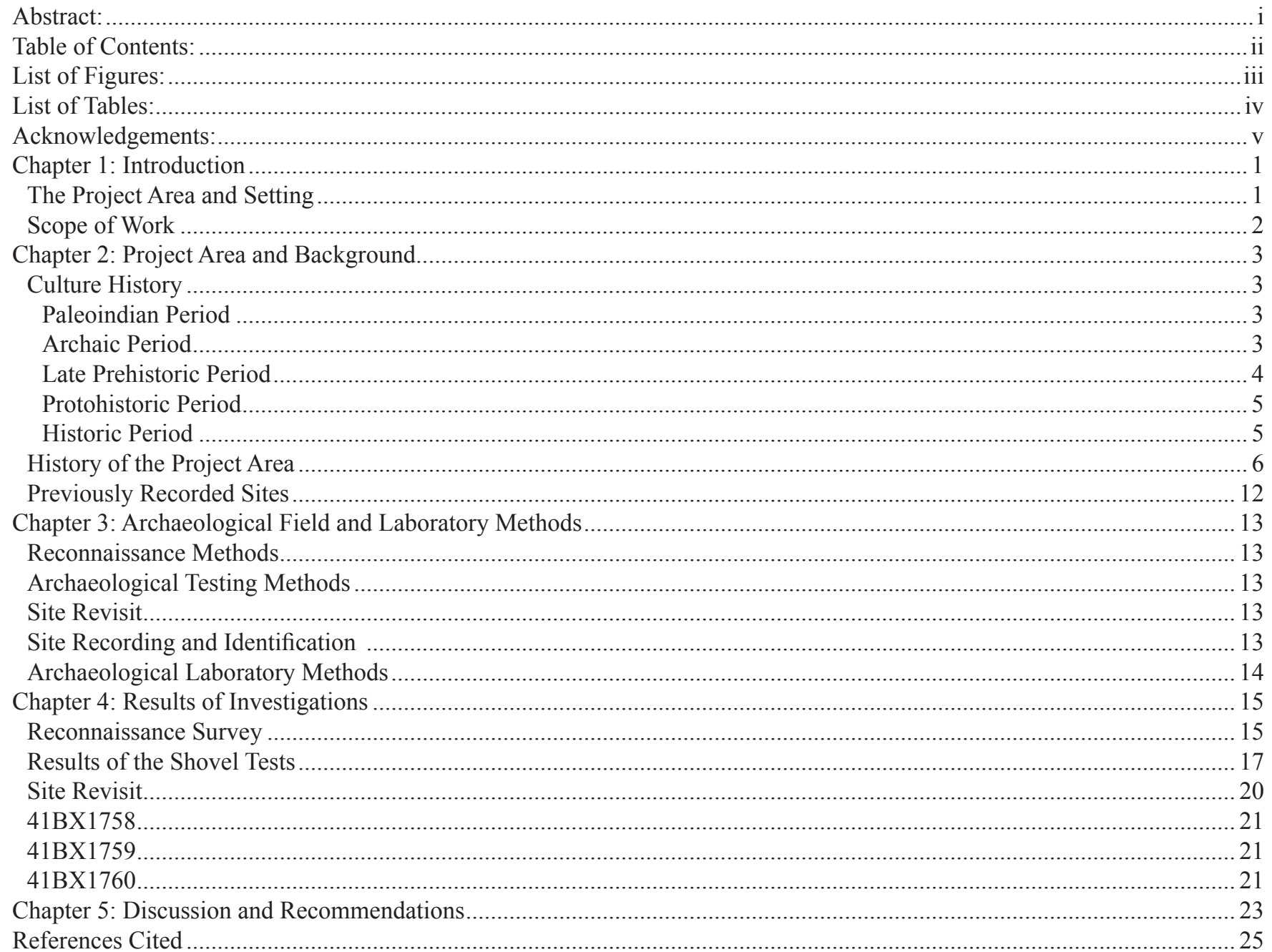




\section{List of Figures:}

Figure 1-1. Location of project area on the USGS 7.5' Schertz topographic quadrangle map............................................... 1

Figure 2-1. Map drawn in 1887 by John D. Rullmann showing the project area within the Francisco

Villareal Survey \#309.

Figure 2-2. Photograph of the Heirholzer-Kruse farmhouse. ……............................................................................

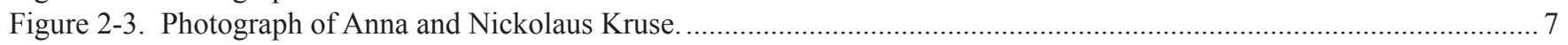

Figure 2-4. Photograph of the Kruse Family in front of the barn ca. 1919; (1-r) Dorothy, Marie,

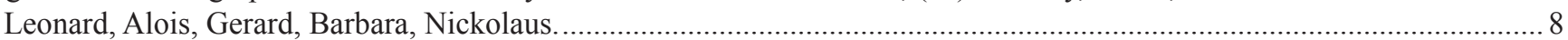

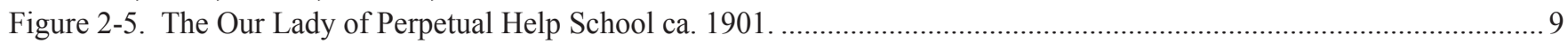

Figure 2-6. Photograph of Walter and Alma Biesenbach ca. 1917............................................................................... 9

Figure 2-7. The Alois Kruse Family ca. 1946 (1-r) Clarence, Bernice, Walter, Jane, David, Alois....................................... 10

Figure 2-8. Bernice Kruse's drawing of the Kruse Farm as she remembered in 2004 .................................................... 11

Figure 2-9. Alois Kruse on tractor ca. 1945

Figure 4-1. Aerial of area showing the amount of disturbance due to construction activities at time of survey...................... 15

Figure 4-2. Location of shovel tests, isolated finds, and 41BX15 within the project area. ................................................ 16

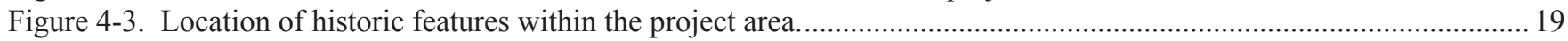

Figure 4-4. Photograph of the trash concentration along western branch of Salatrillo Creek...........................................220

Figure 4-5. Standing metal structure, possibly a cowshed, located in the northwestern portion of the project area................20

Figure 4-6. Boundary of 41BX1758 showing shovel tests and isolated find..................................................................2.

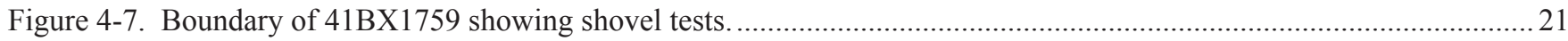

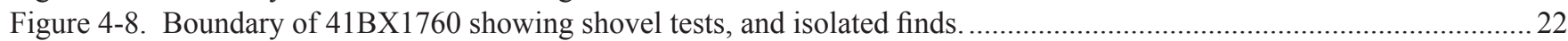




\section{List of Tables:}

Table 4-1. Tools and Cores Recovered During the Reconnaissance and Survey of the Project Area

Due to Construction Activities at Time of Survey.....

Table 4-2. Debitage Recovered During the Reconnaissance and Survey of the Project Area............................................. 17

Table 4-3. Presence of Burned Rock in the Shovel Tests Excavated During the Survey ....................................................... 17

Table 4-4. Debitage Recovered from the Shovel Tests During the Revisit of 41BX15 …................................................2 21 


\section{Acknowledgements:}

The author would like to express thanks to the individuals that aided in the successful completion of the project. Special thanks go to Pete Aristeguieta, the Project Manager for Broaddus Project Control, who aided in coordinating with CAR and the construction site allowing access to the project area. Also, thanks to the Clay and Alois Kruse for providing much information concerning their family's history within the project area.

The author would like to thank the field crew, which consisted of Nate Devito, Cyndi Dickey, Lindy Martinez, Jason Perez, and Joey Thompson. Cynthia M. Munoz served as Principal Investigator. All lab processing and curation was done under the supervision of Marybeth Tomka. Thanks also go to Bruce Moses and Leonard Kemp for help with the GPS, production of field maps, and production of the figures in the report. Bruce Moses served as technical editor. Also, thanks to Dr. Steve Tomka, CAR Director, for his guidance during the course of the project. 



\section{Chapter 1: Introduction}

Ford, Powell and Carson, Inc., contracted with Alamo Community Colleges to carry out and/or oversee the planning, design and construction phases for the Northeast Lakeview College campus in the City of Live Oak in northeast Bexar County. The construction phase of the project impacted 238acres inside Loop 1604 North. Following Ford, Powell and Carson's notification of the Texas Historical Commission (May 17, 2007), the THC requested that a pedestrian survey of the portions of the tract not yet impacted by the ongoing construction, 173-acres, be conducted. Ford, Powell and Carson contracted the University of Texas at San AntonioCenter for Archaeological Research (UTSA-CAR) to conduct a combination reconnaissance and pedestrian survey of 100 percent of the project area. The archaeological work is necessary to address the requirements of the Antiquities Code of Texas. south, the Blackland Prairie in the south and east, and the Edwards Plateau across the northern half. Live Oak in northeastern Bexar County lies on the edge of the Edwards Plateau region. The Edwards Plateau lacks deep soils suitable for farming but is perfect for cattle grazing. A third of Bexar County is under cultivation while another third is used as cattle range. The soils of the survey area are described as the Houston Black-Houston association (Taylor et al. 1991).

Three major geographic regions meet in Bexar County: the Edwards Plateau, the Blackland Prairie, and the South Texas Plains (SCTRWPG 2007). The Edwards Plateau gradually slopes to the southeast and ends in the Balcones Escarpment (Taylor et al. 1991). The limestone based Edward's Plateau is characterized by spring-fed, perennial streams that flow across the Balcones Escarpment (SCTRWPG 2007).

\section{The Project Area and Setting}

The project area is located in the City of Live Oak, just to the northeast of San Antonio, Bexar County, Texas. It falls on the USGS 7.5' Schertz topographic quadrangle map (Figure 1-1). Martinez Creek bounds the project area on the west and two unnamed tributaries flow through it. The project area is located east of IH-35 along Loop 1604. It is bounded by Old Converse Road on the northeast, Kitty Hawk Road on the southeast, Palisades Drive on the northwest, and the Live Oak City Park on the southwest.

The project area is situated in the geographic region referred to as South Texas. The region is bordered by the Edwards Plateau to the north, the Rio Grande River to the south, the Gulf of Mexico coastline to the east, and the Lower Pecos region to the west (Norwine 1995:138). The general topography of the project area is characterized by a gently rolling landscape cross-cut by seasonal drainages. Bexar County is located in the transitional zone between the southern limits of the Edwards Plateau Escarpment and the lower Gulf Coastal Plain.

Three natural regions cross Bexar County: the South Texas Brush Country in the extreme

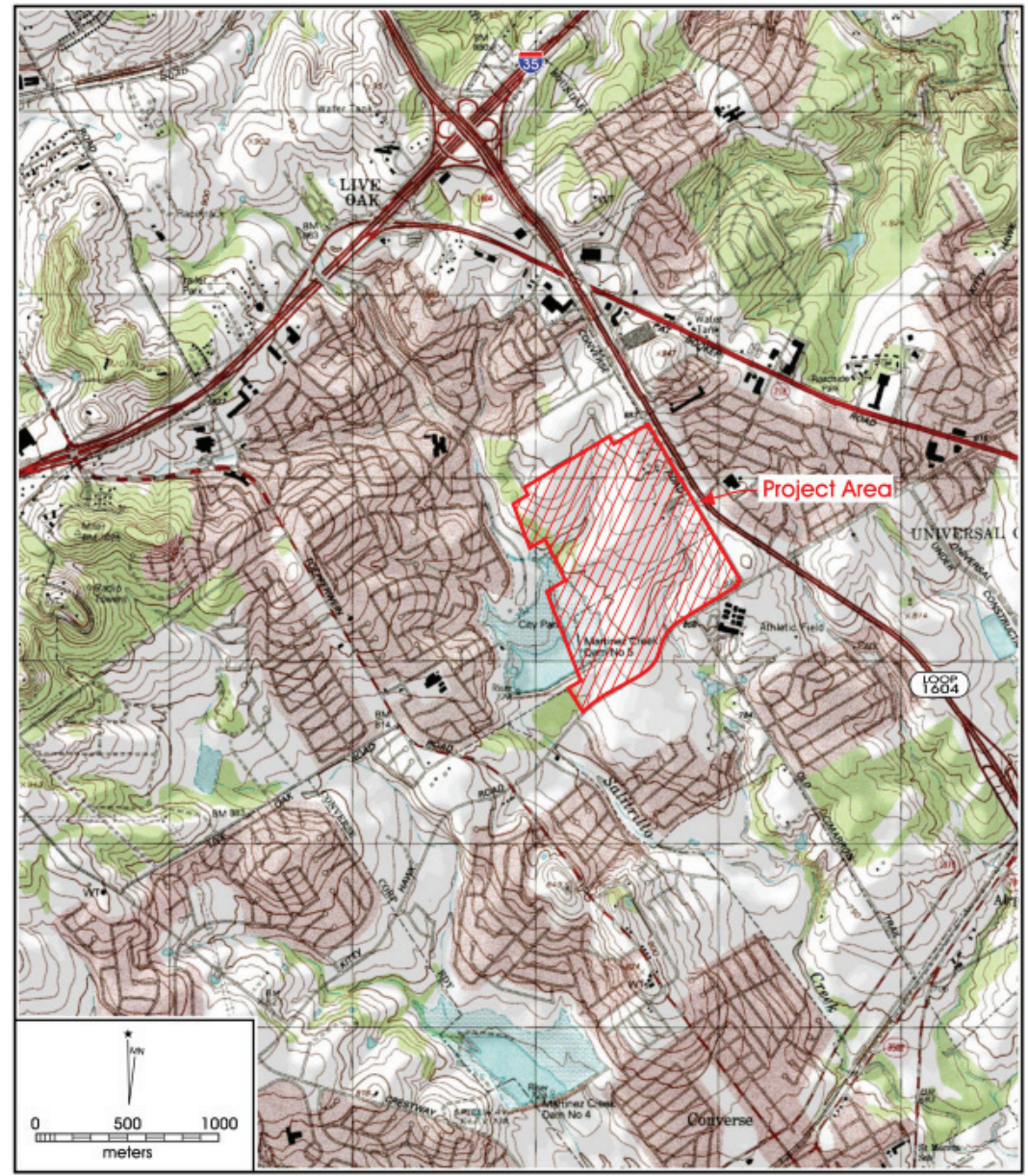

Figure 1-1. Location of project area on the USGS 7.5' Schertz topographic quadrangle map. 
Vegetation in the Edwards Plateau consists largely of bald cypress (Taxodium distichum), live oak (Quercus virginiana), cedar elm (Ulmus crassifolia) and several species of grasses that include bluestem (Schizachyrium and Andropogon spp.), gramas (Boutelous spp.), Indiangrass (Sorghastrum nutans), common curly mesquite (Hiaria belangeri), buffalo grass (Buchloe dactyloides) and Canadian wild rye (Elymus Canadensis; Fentress 1986).

The Blackland Prairies vegetation regime includes a variety of oaks, pecan (Cara illinoiensis), cedar elm (Ulmus crassifolia) and mesquite (Prosopis sp.). Grasses in this region include big bluestem (Andropogon gerardi), little bluestem (Schizachyrium scoparium), Indiangrass (Sorghastrum nutans), switchgrass (Panicum virgatum), sideoats grama (Bouteloua crutipendula), hairy gama (Bouteloua hirsuta), and a variety of others (Fentress 1986).

The South Texas Plains vegetation area supports subtropical dryland vegetation including honey mesquite (Prosopis glandulosa), live oak (Quercus virginiana), blackbrush acacia (Acacia rigidula), huisache (Acacia smallii) and Mexican Paloverde (Parkinsonia aculeate) (Fentress 1986).

Bexar County also falls within two of the six biotic provinces described by Blaire (1950); the Tamaulipan and the Balcones. The Tamaulipan province spans from the Balcones Escarpment south into northeastern Mexico east of the Sierra Madre. It is generally covered with thorny brush species like acacias and mesquite but likely supported more grasses prior to historic modifications to the land (Black 1989).
Climate in South Central Texas is humid subtropical with hot and humid summers (SCTRWPG 2007). The hot weather is persistent from late May through September. The cool season begins about the first of November and extends through March. Winters are typically short and mild with light precipitation. Rainfall in the San Antonio area averages 32.92 inches a year (SRCC 2007; based on monthly averages from 1971 to 2000). Average daily temperatures in 2007 ranged from a low of $37^{\circ} \mathrm{F}$ in January to a high of $84^{\circ} \mathrm{F}$ in August.

\section{Scope of Work}

The archaeological services provided by the CAR associated with the survey of the Northeast Lakeview College Campus included the following: (1) reconnaissance of 100 percent of the 238 acre Area of Potential Effect (APE); (2) an intensive pedestrian survey of the portions of the project area not already disturbed by construction activities, approximately 173-acres; (3) the excavation of a minimum of 58 shovel tests as per THC minimum survey standards; (4) revisit and shovel testing of 41BX15 to determine the current condition of the site; (5) analysis and preparation of collected artifacts for permanent curation; (6) preparation of a draft report detailing the findings and recommendations for review by the city's Historic Preservation Office, the Texas Historical Commission, and the project Sponsor. After comments are addressed, the final report will be produced to satisfy the permit requirements. Cultural material collected during the survey and all project-related documents will be permanently housed at the Center for Archaeological Research. 


\title{
Chapter 2: Project Area and Background
}

\author{
Kristi M. Ulrich and Antonia L. Figueroa
}

\section{Culture History}

The culture history of the region, in particular Bexar County, spans nearly 11,500 years. There are four periods discernible by changes in hunting and gathering technologies, material culture and the arrival of non-indigenous populations. These are Paleoindian, Archaic, Late Prehistoric and Historic. Coherent culture chronologies of Central Texas by Collins (1995) and Prewitt (1981) are the standard summaries adhered to by many researchers. Collins' culture chronology for Central Texas (1995 and 2004) is used as a basis in this section supplemented by the results of recent research.

\section{Paleoindian Period}

The earliest culture period recorded is the Paleoindian Period, which marks the first signs of human populations in the New World. It coincides with the end of the Pleistocene and spans roughly from $11500-8800$ B.P. (Collins 1995 and 2004). Current research has confirmed absolute dates at three sites in Texas. The earliest is from the Aubrey site in Denton County, with radiocarbon assays of $11,542 \pm 111 \mathrm{~B}$. P. and 11, $590 \pm 93$ B. P (Bousman et al. 2004: 48). Environmental data suggest that the climate during the Late Pleistocene was wetter and cooler than it is today (Mauldin and Nickels 2001; Toomey et al. 1993), shifting to gradually drier and warmer conditions during the Early Holocene (Bousman 1998).

Early perceptions of Paleoindian populations viewed these hunter-gatherers as ranging over wide areas in pursuit of now extinct megafauna. This view of Paleoindian peoples, much like the dating of this period, is now being reassessed. While certainly exploiting Late Pleistocene megafauna, these peoples are perhaps better characterized as generalized hunter-gatherers with considerable reliance on small game and plants. The Lewisville (Winkler 1982) and Aubrey sites (Ferring 2001) possess faunal assemblages with a wide range of taxa that not only include large mammals but small to medium ones as well. Little information is available on the consumption of plant resources during this cultural period, though according to Bousman et al. (2004) the Late Paleoindian component at the Wilson-Leonard site reflects diverse exploitation of riparian, forest and grassland species. Analysis of skeletal remains indicates that the diets of the Paleo-Indian and Early Archaic hunter-gatherers may not have differed so greatly (Bousman et al. 2004 after Powell and Steele 1994).
Clovis and Folsom fluted projectile points used for hunting megafauna characterize the material culture from the early Paleoindian sub-period. Projectile points, such as Plainview, Dalton, Angostura, Golondrina, Meserve, and Scottsbluff, are diagnostic of the late Paleoindian sub-period. Typical site types associated with the early Prehistoric (Clovis) subperiod are camp, lithic procurement, kill, cache, ritual and burial sites (Collins 1995). Meltzer and Bever (1995) have documented 406 Clovis sites in Texas. One of the earliest documented Paleoindian sites, 41RB1, was a small playa site near Miami in Roberts County, Texas (Bousman et al. 2004:15). According to radiocarbon assays, the maximum age for the Miami site is $11,415 \pm 125 \mathrm{~B}$. P. (Bousman et al. 2004: 47).

The most notable sites in Bexar County that contain Paleoindian components include St. Mary's Hall (Hester 1978 and 1990), and Pavo Real (Collins et al. 2003). St. Mary's Hall, 41BX229, is located in northern San Antonio, Bexar County. The site was first encountered in 1972 during the construction of a house just outside the property of the St. Mary's Hall institution (Hester 2007). The Pavo Real Site, 41BX52, is located along Leon Creek in northwest Bexar County. The site was first encountered in 1970 and has been subsequently excavated (Collins et al. 2003).

\section{Archaic Period}

The Archaic Period spans from ca. 8800 B.P. to 1200 B.P. Early Archaic, Middle Archaic and Late Archaic periods divide this period. In addition, Johnson and Goode (1994) divide the Late Archaic sub-period into Late Archaic I and Late Archaic II. During the Archaic, there is a shift in subsistence with a greater emphasis on the exploitation of specific local environments. Differences between subperiods are marked by changes in material culture and site characteristics. Hunting strategies focus mainly on medium to small game along with continued foraging for plant resources (Collins 1995).

\section{Early Archaic}

According to Collins (1995), the Early Archaic spans from 8800 to 6000 B. P. Early Archaic projectile point styles include Angostura, Early Split Stem, Martindale and Uvalde (Collins 1995). The climate during the Early Archaic is described as drier than the Paleoindian period with a return of grasslands (Bousman 1998). Megafauna of the Paleoindian period could 
not subsist in the new ecosystem and gradually died out. With the extinction of megafauna, the Early Archaic exploitation of medium to small fauna intensified.

Data recovered from the Wilson-Leonard site reveals the continuation of Paleoindian period projectile point forms and the use of small to medium size hearths. The appearance of earth ovens implies another shift in subsistence patterns. Collins et al. (2003) suggest that the earth ovens at WilsonLeonard were used to cook wild hyacinth along with aquatic and terrestrial resources. Information derived from Early Archaic human remains from Kerr County (Bement 1991) indicates a diet low in carbohydrates in relation to Early Archaic populations in the Lower Pecos area. Stable-carbon isotopes on skeletal samples collected from the Bering Sinkhole in Kerr also suggest a low reliance on $\mathrm{C}_{3}$ plants and animals that consume such vegetation. This is in conjunction with a low to moderate rate of tooth enamel hypoplasia (Johnson and Goode 1994:24).

\section{Middle Archaic}

Date ranges for the Middle Archaic span from 6000 to 4000 B.P. Collins (1995) and Weir (1976) suggest that there was a population increase during this sub-period. The climate was gradually drying as the onset of the Altithermal drought began. Demographic and cultural change likely occurred in response to the hotter and drier conditions. Middle Archaic projectile point styles include Bell, Andice, Calf Creek, Taylor, Nolan, and Travis. Johnson and Goode (1994) postulate that culture transmission from the Lower Pecos region explains the appearance of new point styles in the sub-period.

Middle Archaic subsistence focused on exploitation of resources clustered in riverine environments (Black 1989). The accumulation of burned rock middens during the Middle Archaic reflects this focus on plant resources (Black 1989; Johnson and Goode 1994). Current research has reassessed when the use of burned rock middens intensified. Data from Camp Bowie suggest that intensification occurred in the latter Late Prehistoric Period (Mauldin et al. 2003). Little is known about burial practices during this culture period, though a sinkhole in Uvalde County (41UV4) contained 2550 individuals (Johnson and Goode 1994:28).

\section{Late Archaic}

The Late Archaic is the final sub-period of the Archaic and spans from 4000-1200 B.P. (Collins 2004). The Late Archaic is marked by the introduction of Bulverde, Pedernales, Kinney, Lange, Marshall, Williams, Marcos, Montell, Castroville, Ensor, Frio, Fairland and Darl projectile points. During the early part of the Late Archaic, there were fluctuations in temperature and rainfall. Populations are believed to have increased through this sub-period. This change in climate marks Johnson and Goode's (1994) Late Archaic II.

Some researchers believe that the use of burned rock middens ceased at this time, but current research is challenging this notion (Black and Creel 1997; Mauldin et al. 2003). Skeletal evidence from Late Archaic cemeteries in Central and South Texas, suggests the region saw increasing populations that may have prompted the establishment of territorial boundaries resulting in boundary disputes (Nickels et al. 1998). Human remains dating to this sub-period have been found near the Edward's Plateau at the Bering Sinkhole. Dental evidence shows a high rate of enamel hypoplasia at this time (Johnson and Goode 1994). The rate of enamel hypoplasia in the Late Archaic increased in comparison to rates in previous subperiods, indicating increasing nutritional stress.

\section{Late Prehistoric Period}

This period begins ca. 1200 B. P. (Collins 1995, 2004) and lasts until the Protohistoric Period (ca. 700 B.P.). The term Late Prehistoric is commonly used to designate the period following the Late Archaic in Central and South Texas. A series of distinctive traits marks the shift from the Archaic to the Late Prehistoric Period, including the technological shift to the bow and arrow and the introduction of pottery. The period includes two phases: The Austin Phase and the Toyah Phase.

At the beginning of this period, environmental conditions were warm and dry. More mesic conditions appear to accelerate after 1000 B.P. (Mauldin and Nickels 2001). Subsistence practices remain relatively unchanged, especially during the Austin Phase. Projectile point styles associated with the Austin Phase include Edwards and Scallorn types while in the Toyah Phase the Perdiz projectile point is prevalent (Collins 1995). Though much of the technology and subsistence practices remained unchanged compared to the Late Archaic, most researchers agree the early Late Prehistoric sub-period (i.e. Austin Phase) was a time of population decrease (Black 1989:32).

Radiocarbon data have revealed that a number of burned rock middens in Central Texas were used long after the Archaic and throughout the Late Prehistoric. Moreover, the "heyday of middenery began after A. D. 1 and peaked during the Late Prehistoric" (Black and Creel 1997:273). Radiocarbon dates from Camp Bowie middens concur with arguments set forth by Black and Creel (1997) that burned rock middens 
are primarily a Late Prehistoric phenomena (Mauldin et al. 2003).

Beginning rather abruptly at about 650 B.P., a shift in technology occurred. This shift is characterized by the introduction of blade technology, the appearance of the first ceramics in Central Texas (bone-tempered plainwares), and the use of Perdiz arrow points and alternately beveled bifaces (Black 1989:32; Huebner 1991:346). Prewitt (1981) suggests this technology encroached from north-central Texas. Patterson (1988), however, notes the Perdiz point was first seen in southeast Texas by about $1350 \mathrm{BP}$, and was introduced to the west some $600-700$ years later.

Ricklis (1995) contends that ceramics became a part of the archaeological record in Central Texas beginning about A. D. 1250/1300. Early ceramics in Central Texas are associated with Toyah Phase components and referred to as Leon Plain. The earliest dates for Leon Plain are relative and based on associations with "Toyah" assemblages. The Leon Plain ceramic type includes undecorated, bone-tempered bowls, jars, and ollas with oxidized, burnished or floated exterior surfaces (Ricklis 1995). Although there is a typical set of attributes associated with Leon Plain, there is notable variation within the type. This variation is typically attributed to differences in manufacturing methods and cultural affiliation (Black 1986; Johnson 1994; Kalter et al. 2005). Stable carbon and nitrogen isotope data suggests that vessels were utilized in the processing of bison bone grease/fat, mesquite bean/bison bone grease and deer/bison bone grease (Quigg et al. 1993).

Huebner (1991) suggests that the sudden return of bison to South and Central Texas during the Late Prehistoric resulted from a xeric climate in the plains north of Texas and increased grass production in the Cross-Timbers and Post Oak Savannah in north-central Texas. Together these formed a "bison corridor" into the South Texas Plain along the eastern edge of the Edwards Plateau (Huebner 1991:354-355). Settlement shifts into rock shelters such as Scorpion Cave in Medina County (Highley et al. 1978) and Classen Rockshelter in northern Bexar County (Fox and Fox 1967) have been noted during this time. Cemeteries from this period often reveal evidence of inter-group conflict (Black 1989:32).

\section{Protohistoric Period}

The transitional period between the Late Prehistoric and Historic period is usually deemed the Protohistoric Period. This period is not well documented and is marked by the end of the Toyah Phase, roughly 1250/1300 A.D. to A. D. 1600/1650 (Hester 1995), and the beginning of Spanish explorations of the area (ca. 1528). The period concludes with the establishment of a strong Spanish presence in the region in the late 1600 s and early 1700 's. Sporadic encounters between the indigenous populations and Europeans occurred at this time. Identifying this period archaeologically is problematic in that a clear set of associated material culture is lacking. Protohistoric sites may have mixture of Late Prehistoric and Historic artifacts.

\section{Historic Period}

The Historic Period is marked by the arrival of Europeans into the area. The first Europeans to enter Texas were Alvar Nuñez Cabeza de Vaca and the survivors of the Narvaez expedition in 1528. Between 1528 and the late 1600s, Spanish excursions into the Texas territory were limited. Although Europeans began to settle the territory at the beginning of the eighteenth century, the inhabitants of the region remained mostly Native Americans until the late 1700s.

The first settlement in San Antonio was Mission San Antonio de Valero in 1718. Located at the headwaters of San Pedro Creek, Presidio San Antonio de Bexar was established shortly after to offer protection to the mission inhabitants (Chipman 1992: 117). Although the mission was at some distance from the project area, a review of historic maps reprinted in Jackson $(1986: 92,324)$ indicates that Monte Galván, the mission ranch, may have been located in the vicinity of the APE. One of the maps in Jackson (1986:324) places Monte Galván east of the current route of Loop 1604. The second map (Jackson 1986:92) suggests that the boundaries of Monte Galván encompassed the APE.

Soon after the establishment of Mission San Antonio de Valero, San Antonio became the site for four other missions and the Spanish settlement of Villa de Bexar, populated by an immigration of Canary Islanders. By the late 1700s, San Antonio was a provincial Spanish town thriving in the midst of the harsh Texas frontier.

During the early part of the nineteenth century, New Spain gained its independence as a result of the Napoleonic invasion of its motherland, forming the new nation of Mexico. Mexico enabled the additional settlement of Texas by allowing Anglo settlers, led by Stephen F. Austin, the opportunity to inhabit the region. This influx of Anglo settlers was followed by a movement for independence from Mexico in the 1830s. San Antonio played an integral role in the political uprisings that eventually resulted in the Republic of Texas. The Republic of Texas was incorporated into the United States in 1845. At this point, San Antonio's population consisted of a mix of Anglo, Native, and Hispanic inhabitants. San Antonio boomed with the arrival of the railroad in 1877, allowing for much easier transportation of people and goods in and out of the city. 


\section{History of the Project Area}

This section presents a brief history of the ownership and use of the project area. On November 28, 2007, the project archaeologist met with Alois and Clarence (Clay) Kruse at the project area to talk about their family history and use of the land. Additional information was gathered from the Kruse Family webpage (Kruse 2007) and research of the deed history of the property.

In addition to having been part of Monte Galván, the project area is part of the Francisco Villareal Survey 309 (Figure 2-1). In September of 1847, 1280 acres of the F. Villareal Survey No 309 was conveyed to W. H. Meriwether by the State of Texas, undersigned by J. Pickney Henderson (BCDR G1:415). In 1881, William Schmid purchased the same property from the New York and Texas Land Co. Ltd. for approximately $\$ 1750$ (BCDR 15:621). William Schmid and his wife, Auguste, later sold the 1280 acres to Joseph Heirholzer on December 28, 1882 for $\$ 4500$ (BCDR 21:488-489). Joseph Heirholzer, Jr. conveyed $2511 / 2$ acres to Engelhardt Kruse on October 18, 1890 for a sum of $\$ 3100$ (BCDR 82:452-455).
Engelhardt Kruse, his wife, Marianna, and their five children, Nickolaus, Clemens, Robert, Josephine and Mary came to the United States in 1884. After arriving in Texas, the family first lived in Guadalupe County near the town of Santa Clara. Engelhardt rented a piece of land and farmed it to make a living for the family. Nickolaus was 14 when his family arrived in Guadalupe County, and he and his brothers found work to help out the family. Family records indicate that it is possible that none of the children attended school during their first few years in Texas. The Kruse's attended church in New Braunfels at St. Peter and Paul Catholic Church (Kruse 2007).

In 1890, Engelhardt Kruse purchased the $251 \frac{1}{2}$ acre farm from Joseph Heirholzer, Jr. A small one story house with a cellar was already standing on the property, and the family quickly moved in. The house was approximately 800 square feet, with a porch attached to the back. The attic was later finished off to serve as additional space (Figure 2-2). The farmhouse was still standing in 1957, when Kruse sold the property. The destruction date of the farmhouse is unknown. Alois Kruse recalls that his father, Nickolaus,

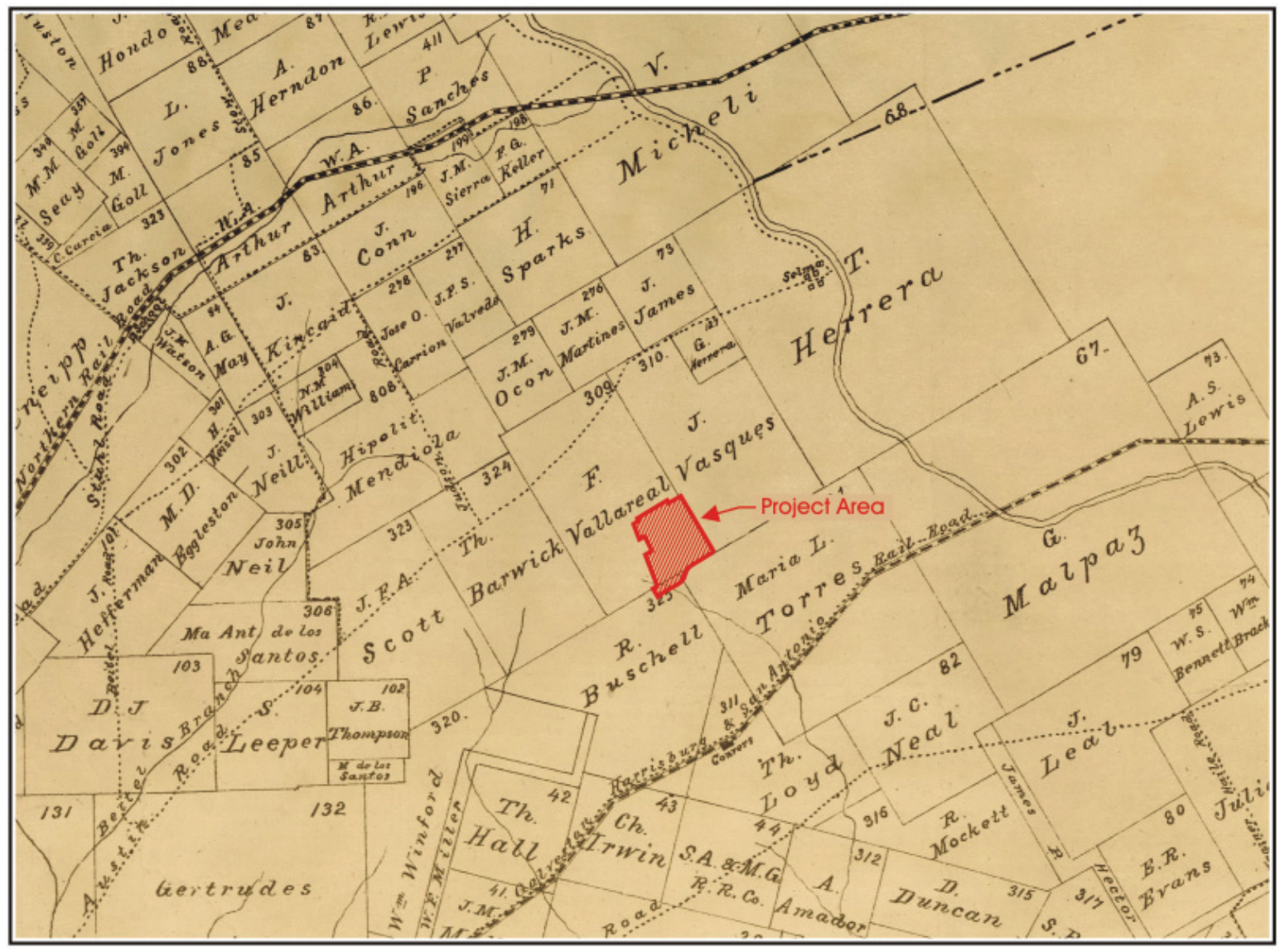

Figure 2-1. Map drawn in 1887 by John D. Rullmann showing the project area within the Francisco Villareal Survey \#309. 


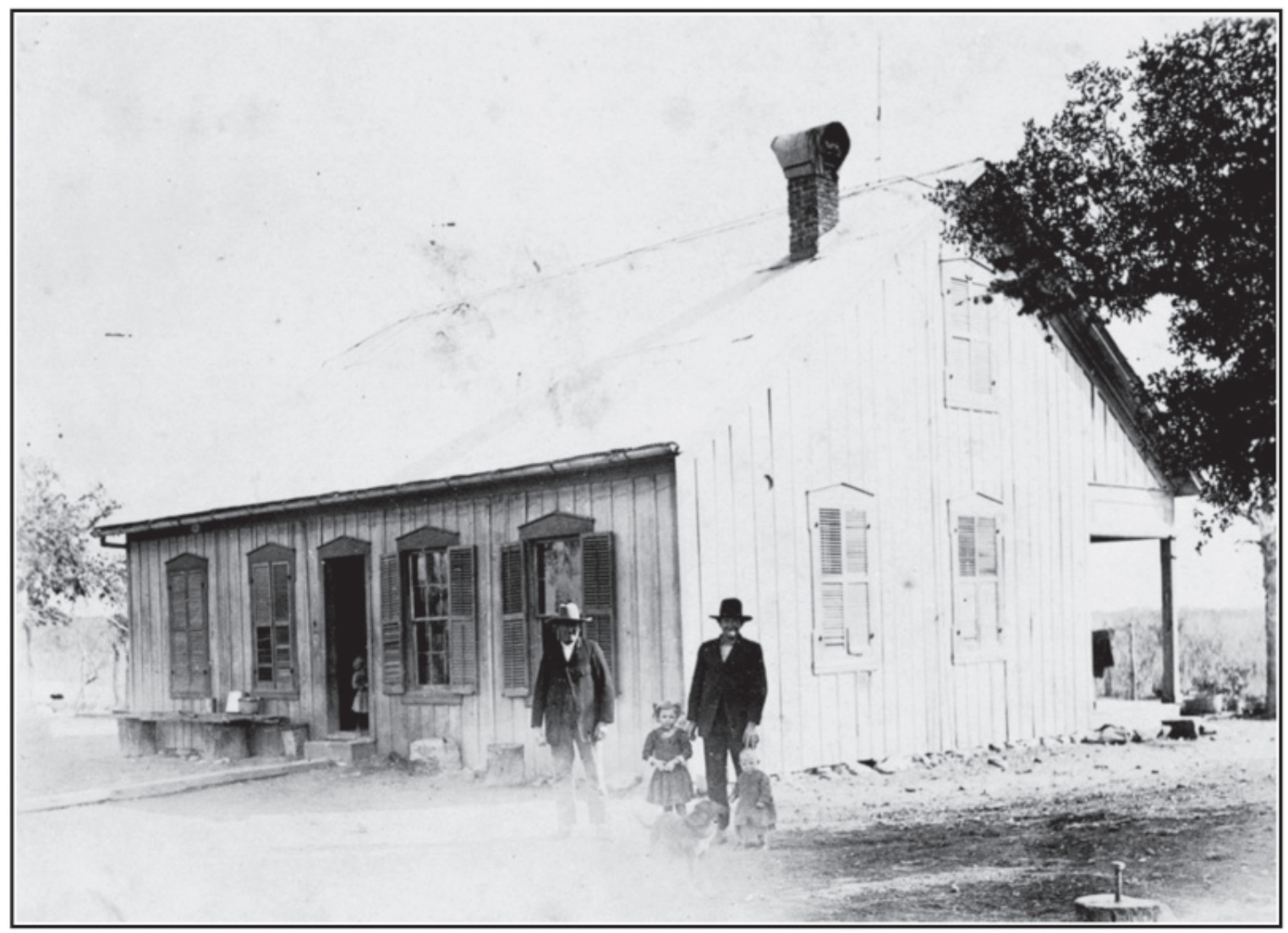

Figure 2-2. Photograph of the Heirholzer-Kruse farmhouse.

mentioned that there was a log cabin on the property as well (Personal Communication 2007). It may have been located downstream along the eastern branch of the Salatrillo Creek, but was no longer standing by the time Alois was born in 1913. In 1891, Marianna Kruse died in childbirth, the child died shortly after. Engelhardt and the children remained on the farm, with Nickolaus and the older siblings helping their father with the heavy work (Kruse 2007). During the later portion of the 1890s, Nickolaus attended a two-room school known as the Lookout School located approximately 4 miles from the farm.

Between 1898 and 1905, all of Engelhardt's children, with the exception of Nickolaus, married and moved off the farm. In 1904, Engelhardt Kruse divided the farmland into two portions and sold the northern 125 acres to Clemens Kruse, Nickolaus' brother, for a sum of $\$ 1875$ (BCDR 232:203). In October of 1905, Clemens sold the property to Alois Hillmeyer for a sum of $\$ 2750$ (BCDR 229:595). It was at this time that Nickolaus met Anna Marie Hillmeyer, his future wife. Anna was one of six children of Alois and Magdalena Hillmeyer. The Hillmeyers had migrated from the Bavarian region of
Germany in 1884. Anna had lived with her family just south of Bracken, TX until they purchased the plot of land from Clemens Kruse (Kruse 2007). In January of 1906, Engelhardt sold the remaining portion of the property to Nickolaus for a sum of \$2000 (BCDR 245:236). Nickolaus and Anna were married on April 23, 1906 at Saints Peter and Paul Catholic Church in New Braunfels (Figure 2-3).

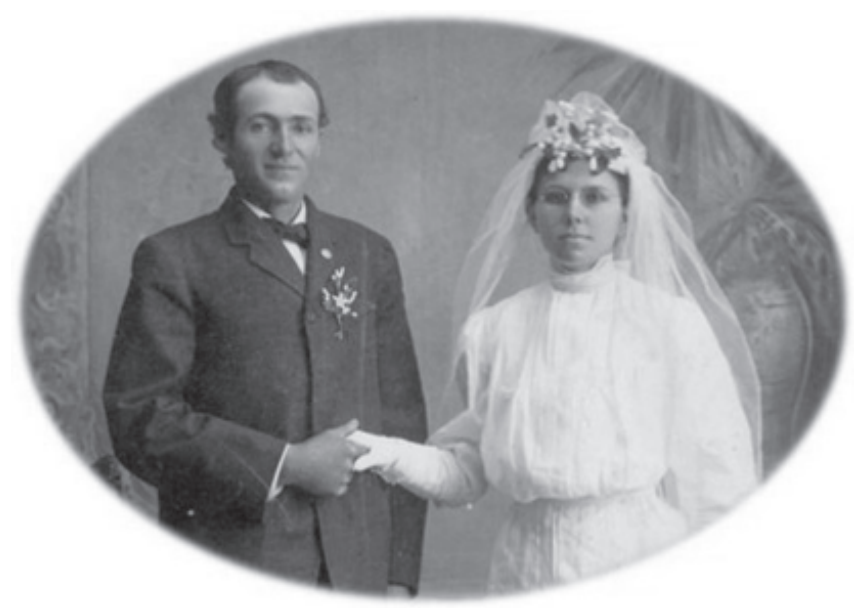

Figure 2-3. Photograph of Anna and Nickolaus Kruse. 
Anna and Nickolaus settled into the southern portion of the project area. Her family lived on the northern portion. They produced cotton and corn on the farm, and raised hogs and chickens. Anna gave birth to seven children over the next twelve years: Dorothy, Marie, Leonard, Alois, Gerard, Barbara, and Engelbert. In January of 1918, shortly after Anna gave birth to the seventh child, Engelbert, both mother and child fell ill with the Swine Flu (Kruse 2007). The Swine Flu, commonly known as the Spanish Flu, was a pandemic that swept the world in 1918 and 1919. An estimated onethird of the world's population was affected by the Spanish Flu. The pandemic appears to have hit in three waves at approximately the same time in Europe, Asia, and North America (Taubenberger and Morens 2006). Researchers estimate that the total deaths stemming from the Spanish Flu were at least 50 million, with others arguing it could have been as high as 100 million individuals. The Spanish Flu was unusual in that the mortality rate was greater in young adults than in young children and older adults (Taubenberger and Morens 2006). Anna, and her young infant, did not recover from the flu. The night before Anna died, the children were brought to her room to say their goodbyes (Kruse 2007). Engelhardt Kruse, Nickolaus' father, also died that January.

Nickolaus intended to raise the children on his own, but found shortly after his wife's death that taking care of the young children was not easy. The older children went to school during the day at Our Lady of Perpetual Help Catholic School in Selma Texas. At that time, Dorothy was 11, Marie was 10, Leonard was 8, Alois was about 6, and Gerard and Barbara were the youngest (Figure 2-4). When school let out, Dorothy and Marie would watch the younger kids, and Leonard would help Nickolaus by doing chores on the farm. During the day, Alois, Gerard, and Barbara were left on their own. This arrangement seemed to work in the beginning, until Alois and Gerard set fire to some cotton bales in the attic of the farmhouse. Nickolaus was close enough to the building to see the flames and was able to toss the bales outside before the farmhouse caught on fire. Immediately after this incident, Nickolaus made arrangements for Alois to stay with Uncle Alois and Aunt Josephine (Kruse) Siebold. Gerard and Barbara were sent to live with Clemens and Anna Kruse. These arrangements lasted until Dorothy was out of school, possibly a year and a half later in 1921 . When Dorothy was able to give full time care to her younger siblings, Alois, Gerard, and Barbara returned home.
All of the children attended school at Our Lady of Perpetual Help Catholic School (OLPH) (Figure 2-5). The school had its beginnings in 1901, with an initial class of 40 students. The students were taught by two sisters from the Sisters of the Divine Providence who had been at the Our Lady of the Lake convent. Each day, upon arriving at the school, the students helped with the chores by gathering firewood, sweeping the classroom, and attending to any other needs of the school. The students spoke mainly German in their first years of school. All lessons were written on slate boards. Most students attended classes until the sixth or seventh grade, and then would stop attending school to help on the farm. If it was possible for further education, the students would have to travel into San Antonio to attend high school (OLPH 2007). The Kruse family owned two horse-drawn buggies that the family used throughout the years. One was a two-seater, and the other was a one-seater. Typically the oneseater buggy was used to get to school everyday because due to the spacing of the children's ages, not more than two went at a time (Personal Communication 2007). Some students were not as lucky and may have had to walk long distances to get to school.

Nickolaus was a devout Catholic, and was very active in the Our Lady of Perpetual Help Catholic Church. When the church building burned, Nickolaus was active in the efforts to rebuild. Nickolaus and Engelhardt Kruse and Alois Hillmeyer were sponsors at the laying of the cornerstone on March 25, 1912.

Bernice Biesenbach Kruse was the daughter of Walter Biesenbach and Alma Dora Graf. The Biesenbach family arrived in Texas between 1846 and 1854. Walter

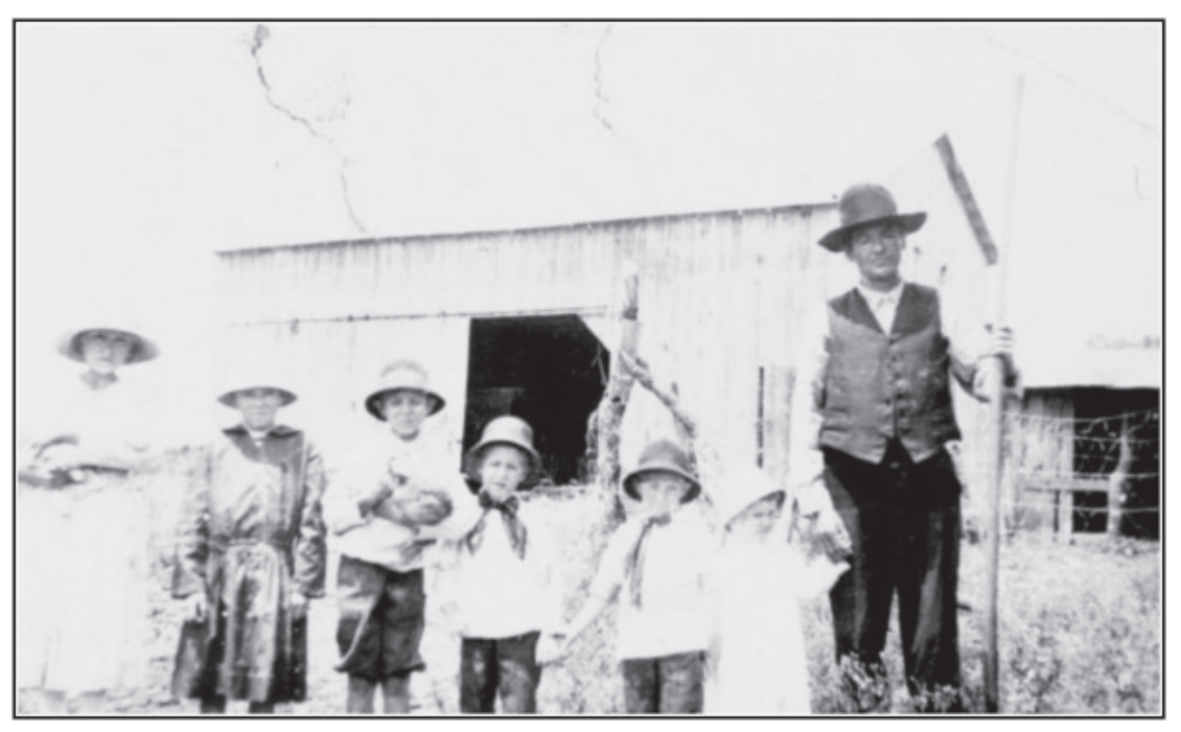

Figure 2-4. Photograph of the Kruse Family in front of the barn ca. 1919; (l-r) Dorothy, Marie, Leonard, Alois, Gerard, Barbara, Nickolaus. 


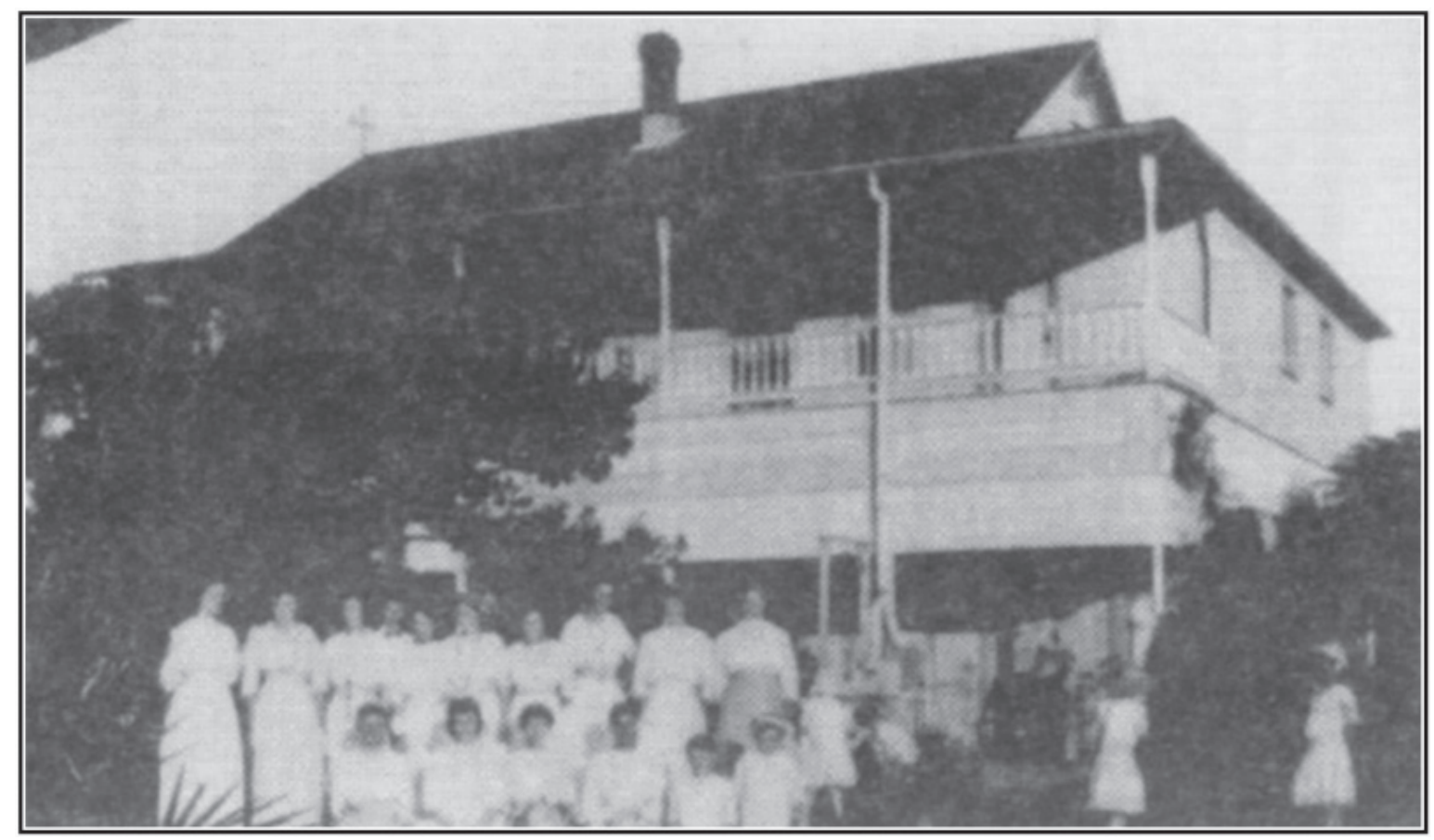

Figure 2-5. The Our Lady of Perpetual Help School ca. 1901.

Biesenbach, the eldest of six children, was born on a farm near Converse in 1895. He attended school at a three-room schoolhouse in Converse until about the sixth grade, the age when children typically left school to help on the farm. His mother died when he was 10 years old. Alma Dora Graf was born in San Antonio in 1902. Her family lived in the city, and appeared to be fairly well off. When Alma was 15 years old and in eighth grade (she likely had more schooling because her family was able to afford it), World War I broke out. Alma told her grandchildren that she remembered people coming to her school and entering people's homes to question their loyalty to the United States (Kruse 2007). During this time, the government was suspicious of people of German descent due to the transmission of the Zimmerman Letter from the German Ambassador in Washington to the President of Mexico (Steen 2007).

Alma and Walter met in early 1917 at a dance near Converse. Walter was a musician and possibly was playing at the event. Walter and Alma were married in June of 1917 (Figure 2-6). She was 15 and he was 22. Over the years, Walter and Alma had six children. Bernice was the second child, born on July 16, 1923. The family lived until the late 1920s on the Robert Biesenbach Ranch just southeast of Schertz. Robert Biesenbach, Walter's father, lost the farm during the Great Depression. At this point, the Biesenbachs moved to the Rittiman Farm, located in Schertz, for a couple years before moving on to a farm located off of FM 78 and FM 1518.
During World War II, the Biesenbachs again moved around before finally settling in Schertz (Kruse 2007).

Alois Kruse met Bernice Biesenbach at a dance held at the Crescent Bend Dancehall located just south of Schertz along Lower Seguin Road. Walter Biesenbach was likely playing

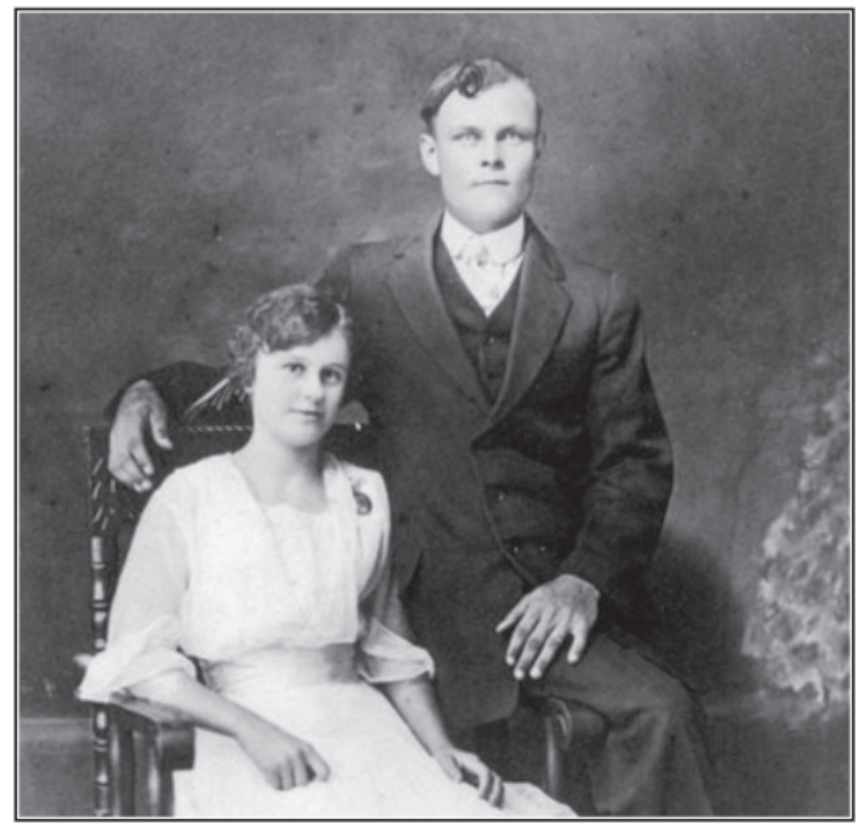

Figure 2-6. Photograph of Walter and Alma Biesenbach ca. 1917. 
with the band that night because he often played at Crescent Bend. Bernice attended the dance with her sister Dorothy, and Alois had a date with another girl. Alois and Bernice ended up dancing quite a bit together. In the end, Alois danced the last dance with his date, took her home, and began dating Bernice.

Alois Kruse married Bernice Biesenbach in November of 1938 (Figure 2-7). Bernice was fifteen years old at the time of the marriage. Alois and Bernice continued to live in the farmhouse that Alois had grown up in. Near the house was a garage and cow pen, to the west was the windmill and Bernice's garden, to the south was the hog pen and chicken coop, and to the southeast was the mule pen and barn (Figure 2-8). Nickolaus remained living on the farm for sometime after Alois and Bernice were married. The marriage produced ten children (four boys and six girls) between the 1940 and 1961. Clarence (Clay) Kruse was the first born to the family and resided with his parents on the farm until 1947, when he was about $7 \frac{1}{2}$ years old. In 1947, the Kruse family moved off the farm to live in the city. Clay attended OLPH for a year and a half before the move. During his first year, the class was held in the rectory. In the summer, a brick schoolhouse was built with aid from the local farmers, including Alois. Clay recalls that it was common for the students to bring eggs, milk, and other goods to the nuns at OLPH.

Alois also grew cotton and corn on the farm. Until the very last years on the farm, Alois plowed the fields using mule-drawn plows. Alois bought an old tractor (possibly pre-dating 1940) in either 1945 or 1946 (Figure 2-9). He would sell the cotton and corn in Converse. There were two cotton gins, one grain silo, and three stores to sell their goods at. In addition to the crops, they raised cows and chickens. Clay Kruse remembers that originally there were only a couple cows, but his mother asked for more. In the end, they had four or five cows, which they would water in the creek when it held water. The eggs from the chickens were sold in Converse. The cream from the cows was taken into San Antonio to sell.

During the November 2007 visit to the project area, both Alois and Clay commented on the difference in vegetation between the Nickolaus Kruse portion of the property and the Hillmeyer portion. The Hillmeyer property had a large number of cedar trees and some dense brush. The Kruse portion consisted more of fields than wooded areas. Alois commented that as far as he could remember there was only one cedar tree on the Kruse property.

For the three years following the Kruse's 1947 move to the city, the farm was worked by relatives. In 1957, Nickolaus Kruse and family conveyed the property in two sections to

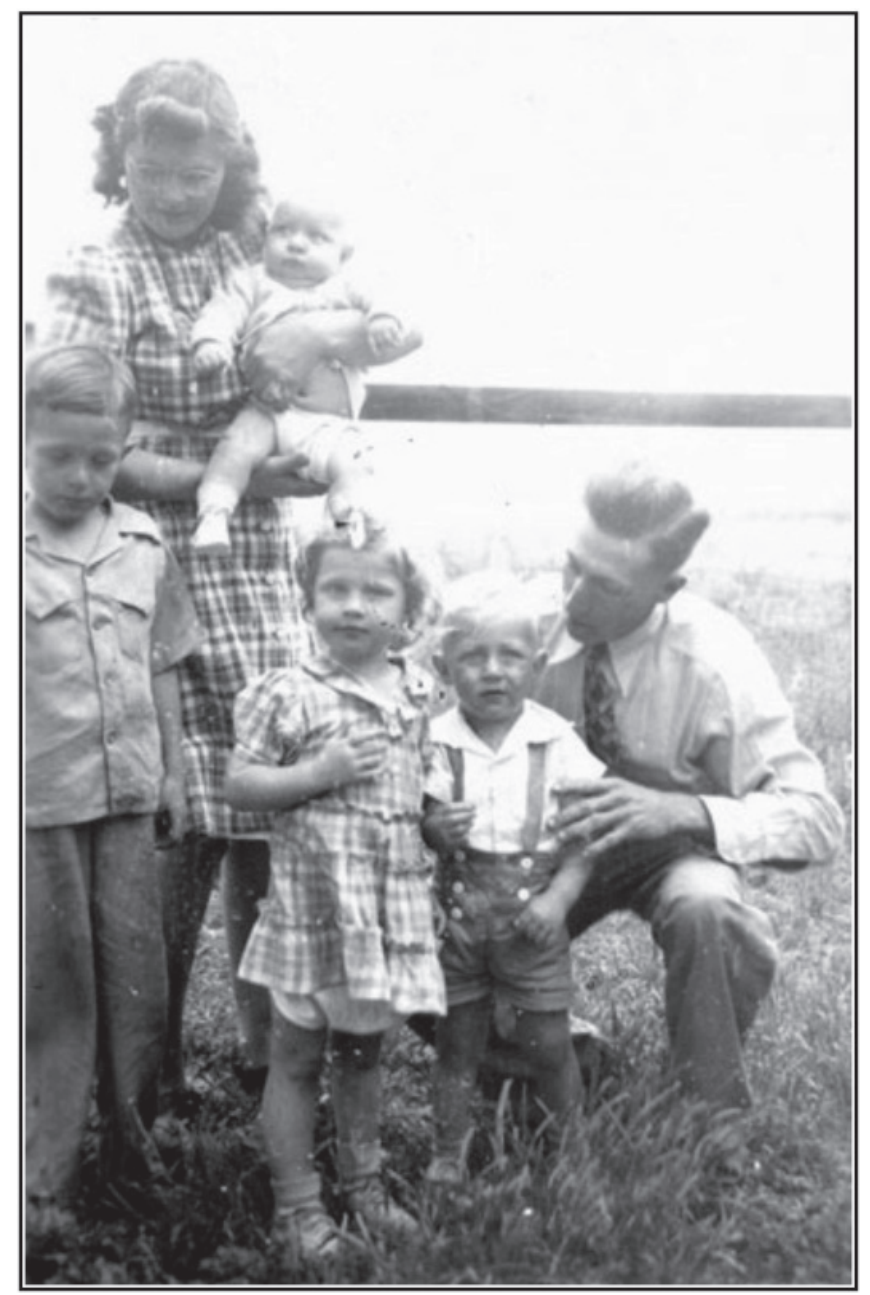

Figure 2-7. The Alois Kruse Family ca. 1946 (l-r) Clarence, Bernice, Walter, Jane, David, Alois.

the Veterans Land Board of Texas. The first parcel consisted of 55 acres, the northern portion of the original 125-acre tract, and was sold for a sum of $\$ 5400$ (BCDR 2859:244). The second parcel consisted of 70-acres, the southern portion of the original 125-acre tract, and old for a sum of $\$ 5600$ (BCDR 2859:252). Immediately the Veterans Land Board sold the 55-acre tract to Victor Doerr for the amount of $\$ 5400$ (BCDR 2865:472). The Veterans Land Board conveyed the 70 -acre tract to Donald Ashbrook for a sum of $\$ 5600$ (BDCR 2856:233). In October of 1950, Victor Doerr leased the 70 adjacent acres from Donald Ashbrook (BCDR 2913:55). The contract stated that the land was to be leased for five years at the rate of $\$ 335$ per year, with the option of purchasing the property after the third year. In March of 1953, Doerr purchased the property from Ashbrook (BCDR 3319:558). The next month, Doerr conveyed the entire 125-acre tract to Thomas Kotowski for a sum of $\$ 6000$ (BCDR 3315:64). In October of 1963, Kotowski sold the 125-acres to Bernice and William Castella for a sum of $\$ 60,000$ (BCDR 5441:437). 


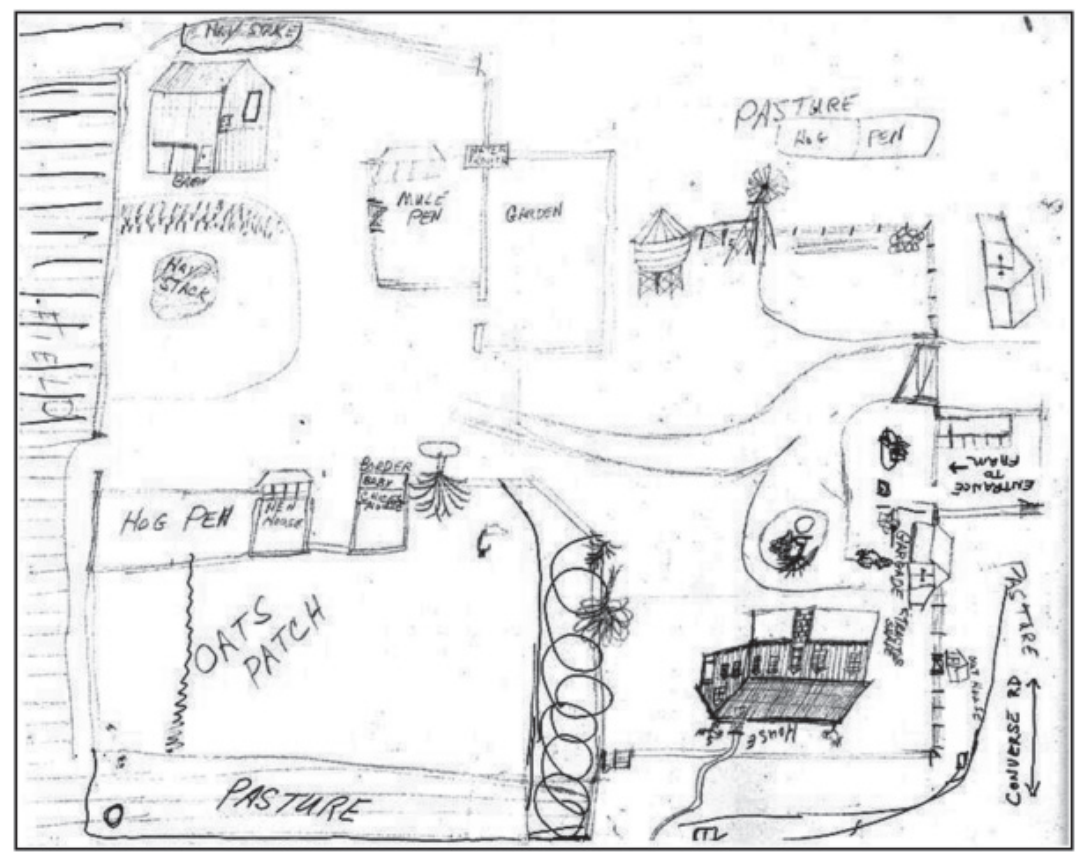

Figure 2-8. Bernice Kruse's drawing of the Kruse Farm as she remembered in 2004.

The 125-acre tract that was conveyed to the Hillmeyer family by Clemens Kruse was also divided up and sold over the years. Alois Hillmeyer sold the northern 57.5 acres to his sonin-law, Max Mayer, for a sum of \$3000 in December of 1916 (BCDR 713:22). At the same time, Alois sold his son, Joseph, the southern 57.5 acres of the 125 -acre parcel for a sum of $\$ 4000$ (BDCR 498:439). The stipulation in both deeds was that the Hillmeyers were to have access to a well and windmill located in the northern portion of the property. This may account for the missing 10-acres in the sales. Also, Joseph Hillmeyer had to allow Alois and his wife, Magdalena, to live out the remainder of their lives on the property, and keep and feed one horse and one cow for them. In December of 1919, Alois released Joseph from the Warranty Deed with Vendor's Lien as payment was made in full (BCDR 582:384).

Alois Hillmeyer transferred the lien on Max Mayer's portion of the property to J. M. J. Wack in February of 1923. At the same time, Mayer secured a mortgage on the property from the Federal Land Bank of Houston (BCDR 715:182). It appears that the property was foreclosed at one point and obtained by Elizabeth and C. L. Quig. On December 10, 1943, Quig sold 57.53-acres to Fred and Helen Barnhouse (BCDR 2001:537). Barnhouse conveyed 57.53 acres to Edward and Esther Eckols for a sum of $\$ 18,583.44$ on July 1, 1959 (BCDR 4331:55). Eckols conveyed 57.53 acres to William and Bernice Castella on April 25, 1966 (BCDR 4431:35). This was in conjunction to the deed in which Nick McFadin Jr. conveyed 81.365 acres to William and Bernice Castella on
April 25, 1966 (BCDR 5559:906). The 57.53 acres from the Eckols was part of the 81.365 in the McFadin deed.

In 1926, Alois and Magdalena executed a Warranty Deed with Vendor's Lien on Joseph's property for a sum of $\$ 5753$ (BCDR 917:450). Joseph Hillmeyer and his wife, Emma, secured a mortgage at an interest rate of $5 \%$ from the Federal Land Bank of Houston; M.H. Gossett served as Trustee (BCDR 920:525). Alois transferred the liens to Federal Land Bank of Houston in November of 1926 (BCDR 928:419). Alois died on March 14, 1927, resulting in the heirs transferring rights and titles of the liens to Magdalena (BCDR 1457:363). In October of 1938, the Federal Land Bank of Houston sold Joseph's portion of the property on the steps of the Bexar County Courthouse due to foreclosure on the property (BCDR 1659:222). The next month, the Federal Land Bank of Houston sold the property to William Grumbles for a sum of $\$ 2600$ and an interest rate of $8 \%$ (BCDR 1670:205). A deed was filed in February of 1939 that seems to have amended the contract to indicate a sale price of $\$ 3250$, with $\$ 650$ paid in front and the interest rate to 5\% (BCDR

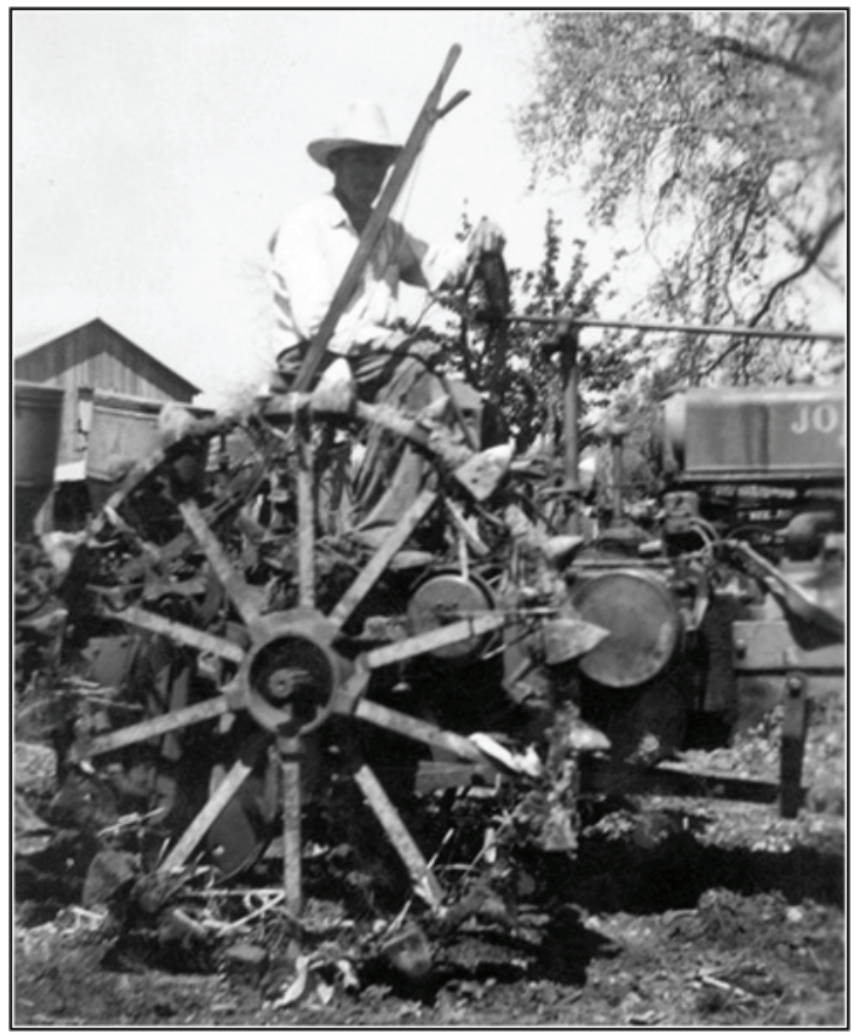

Figure 2-9. Alois Kruse on tractor ca. 1945. 
1677:326). Later in February, Grumbles conveyed the 57.53acres to Max Heimer for a sum of $\$ 2600$, though making the stipulation that $1 / 18$ of the mineral rights associated with the property was retained by the Federal Land Bank of Houston (BCDR 1679:337).

Max Heimer sold 6.83-acres of the 57.53-acre tract to Benhard Reimann for a sum of \$658 in June of 1946 (BCDR 3351:381). In June of 1953, Heimer leased approximately 51 acres to Sam H. Henry (BCDR 3387:217). The Standard Oil and Gas Company released the oil and gas mining lease (likely overseen by Sam Henry) at the end of July, 1953 (BCDR 3907:559). In July of 1961, Heimer sold 40.18 acres to Nick McFadin for a sum of $\$ 12,572$ (BCDR 4623:20). McFadin conveyed this portion of the property as well as the Joseph Hillmeyer portion to the Castellas in 1966.

In May of 1967, the Castellas purchased approximately 7.8 acres from Aubrey A. Autry that had been part of the Eckols 57.53-acre tract (BCDR 5765:785). In August of 1967, the Castellas purchased from the Eckols approximately 7.7 acres of land that they had retained as their dwelling. By 1967, the Castellas had effectively rejoined the majority of the Engelhardt Kruse property into one parcel. On May, 22, 2001, the Castellas conveyed the joined 238-acres to the
Board of Regents of the University of Texas System (BCDR 8886:2036).

\section{Previously Recorded Sites}

The project area is located near Martinez Creek Dam Number 5. One previously recorded site, $41 \mathrm{BX} 15$, is present within its boundaries. Site 41BX15 is a prehistoric workshop that produced heavy utility tools. It was identified during the Martinez Creek Dam Survey conducted by Mardith K. Schuetz in 1977 (THC 2007).

A second previously documented site, 41BX435 is located just outside the western boundary of the tract. The site was documented during the survey of the 70-acre tract of land that would later become the Live Oak City Park. Limited testing was done at the site consisting of a systematic survey and the excavation of two 1 x 1 meter units. Results from the excavations indicate that the site is a relatively large prehistoric occupation site with at least two components evident in the vertical distribution of artifacts. Diagnostic artifacts link the site to the Late Archaic period. The City of Live Oak agreed to cap the site with a layer of sod to prevent further disturbance (Roemer and Black 1977). 


\section{Chapter 3: Archaeological Field and Laboratory Methods}

\section{Reconnaissance Methods}

Reconnaissance of the disturbed portions of the APE was necessary to determine if cultural deposits had been affected during the beginning stages of construction. The reconnaissance was conducted along the 238-acres of the project area that had active construction at the time of the survey. Reconnaissance consisted of archaeologists walking in close transects (approximately 20 meters apart) through the accessible areas. Archaeologists scanned the surface in efforts to locate cultural material. Isolated finds consisting of bifaces and utilized flakes were collected and their locations recorded with Trimble Geo XT GPS units. Historic materials were noted and the locations of concentrations were recorded with Trimble Geo XT GPS units, though no historic artifacts were collected. No shovel tests were excavated during the course of the reconnaissance.

\section{Archaeological Testing Methods}

According to standards of the Texas Historical Commission, a minimum of 58 shovel tests were required to be excavated within the 173 not yet impacted acres of the project area during the survey portion of the project. The number was calculated using the guideline of one shovel test for every three acres. Archaeologists traversed the property on 30-meter transects, placing the shovel tests evenly across the tract to meet the requirements of the Minimum Survey Standards of the Texas Historical Commission. A minimum of eight additional shovel tests were to be excavated during the revisit of 41BX15.

Shovel tests were $30 \mathrm{~cm}$ in diameter and, unless prevented by obstacles or buried features, extended to a depth of $60 \mathrm{cmbs}$. Shovel tests were excavated in $10-\mathrm{cm}$ increments, and all soil from each level was screened through 1/4-inch hardware cloth. All encountered artifacts were bagged with appropriate provenience for laboratory processing, analysis, and curation. A shovel test form was completed for every excavated shovel test. Data collected from each shovel test included the final excavation depth, a tally of all materials recovered from each 10-cm level, and a brief soil description (texture, consistency, Munsell color, inclusions). A profile sketch may have been included on the data recovery form, if warranted. The location of every shovel test was recorded with Trimble Geo XT GPS units. Shovel test locations were sketched onto topographic maps as a backup to GPS provenience information. Any additional observations considered pertinent were included as comments on the standard shovel test excavation form.

Portions of the project area had the potential for producing deep alluvial deposits that extend past the $60 \mathrm{~cm}$ depth of the shovel tests. Initially, CAR proposed to excavate up to four backhoe trenches in terrace deposits that are deeper than what can be effectively sampled through shovel testing. During the course of the survey, it was determined that backhoe trenching was not necessary because it did not appear that cultural material extended below the extent of the shovel tests.

\section{Site Revisit}

To reassess the previously recorded site within the bounds of the project area, the CAR relocated the site using aerial photographs and field maps showing the location of the site as it was recorded during original survey. Once the site was relocated, crewmembers made written observations regarding the types of cultural materials noted on the surface, the relative density of materials, presence/absence of artifact clusters, and temporal diagnostics. A minimum of eight shovel tests were excavated within the site limits to establish the depth of cultural material and sample subsurface deposits. All cultural material encountered in shovel tests was collected and returned to the laboratory for processing.

\section{Site Recording and Identification}

For the purposes of this archeological survey, the minimum requirements for the presence of cultural materials to constitute a site are as follows: 1) Five or more surface artifacts within a $15-\mathrm{m}$ radius (ca. $706.9 \mathrm{~m}^{2}$ ) or; 2) a single cultural feature, such as a hearth, observed either on surface or exposed in shovel testing, or; 3 ) a positive shovel test containing at least three artifacts within a given $10-\mathrm{cm}$ level, or 4) a positive shovel test containing at least five total artifacts, or 5) two positive shovel tests located within $30 \mathrm{~m}$ of each other.

When evidence of cultural materials that meet the minimum criteria for an archeological site was encountered in a shovel test, or on the surface, additional shovel tests were excavated at close intervals $(30 \mathrm{~m})$ to define the extent of the distribution in the cardinal directions. A minimum of six shovel tests were excavated to define the site boundaries within the limits of 
project boundaries, continuing to excavate shovel tests in each direction until no more cultural material was found in two consecutive shovel tests.

Site boundaries were plotted on aerial photographs and/or a topographic quadrangle sheet and location data collected with a GPS unit. Crew members completed a standardized form documenting observations of site disturbance, vegetation, estimated artifact counts by category, and presence of features. All artifacts found in shovel tests were collected for curation. Digital photographs were taken of each site. Texas site forms were prepared for all new sites and amended for all previously recorded sites encountered or relocated during the project.

When artifacts did not meet the minimum definition for a site, they were considering isolated finds. These artifacts were recorded on separate forms and their locations plotted on the maps and aerials. Their locations also were recorded with a GPS unit.

\section{Archaeological Laboratory Methods}

All cultural materials and records obtained and/or generated during the project were prepared in accordance with federal regulation 36 CFR part 79, and THC requirements for State Held-in-Trust collections. Additionally, the materials were curated in accordance with current guidelines of the CAR. Artifacts processed in the CAR laboratory were washed, airdried, and stored in 4-mm zip locking archival-quality bags. Acid-free labels were placed in all artifact bags. Each label contained provenience information and a corresponding lot number written in archival ink, with pencil or laser printed. Tools were labeled with permanent ink over a clear coat of acrylic and covered by another acrylic coat. In addition, a small sample of unmodified debitage from each lot was labeled with the appropriate provenience data. Burned rock that was collected will be discarded. Artifacts are separated by class and stored in acid-free boxes. Digital photographs were printed on acid-free paper, labeled with archivally appropriate materials, and placed in archival-quality sleeves. All field forms were completed with pencil. Upon completion of the project, all collected materials will be housed at CAR. 


\section{Chapter 4: Results of Investigations}

\section{Reconnaissance Survey}

Reconnaissance of the area already disturbed by construction activities was completed to determine the extent and condition of cultural deposits. The reconnaissance survey consisted of walking the portion of the construction area (Figure 4-1) that was accessible and did not pose immediate danger to the crew, while looking for cultural materials or diagnostic artifacts. The archaeologists were evenly spaced across the disturbed areas along the survey transects approximately 20 meters apart. The locations of artifact concentrations and/or the location of isolated artifacts were recorded with the GPS. The area in the immediate vicinity of the buildings under construction was avoided as a safety precaution.

In the northeastern portion of the construction area, along the edge of the creek, a lithic biface was recovered and identified as Isolated Find 1 (Figure 4-2 and Table 4-1). The biface was located in sediments disturbed by bulldozing activities. Approximately 10 meters to the south, a concentration of historic material was located. The historic material was located within the vicinity of the Kruse Family farmhouse, and the quantity and proximity of the material met the criteria for designating the area Field Site 3. Field Site 3 is discussed later in the text.

Table 4-1. Tools and Cores Recovered During the Reconnaissance and Survey of the Project Area Due to Construction Activities at Time of Survey

\begin{tabular}{|l|c|l|c|}
\hline \multicolumn{1}{|c|}{ Provenience } & Count & \multicolumn{1}{c|}{ Description } & Site \\
\hline IF1 & 1 & Biface & \\
\hline IF3 & 1 & Edge Modified & \\
\hline IF5 & 1 & Edge Modified & \\
\hline IF9 & 1 & Biface & \\
\hline IF10 & 1 & Biface & 41 BX15 \\
\hline ST 5 & 1 & Bifacial Core & \\
\hline ST 21 & 1 & Core & \\
\hline ST 94 & 1 & Retouched Flake & \\
\hline
\end{tabular}

Figure 4-1. Aerial of area showing the amount of disturbance due to construction activities at time of survey. 
This page has been

redacted because it

contains restricted

information. 
In the southwest portion of the construction area, several lithic flakes were noted on the surface (Table 4-2) as well as historic materials such as glass, ceramic and metal fragments. Two flakes appeared to have utilized edges (Table 4-1). The prehistoric and historic materials were not located in close proximity, with at least 30 meters between each find. The historic material does not appear to be related to the Field Site 3. The material may have been moved around due to the bulldozing activities that occurred prior to the archaeologists' arrival at the project area.

Table 4-2. Debitage Recovered During the Reconnaissance and Survey of the Project Area

\begin{tabular}{|l|c|c|}
\hline \multicolumn{1}{|c|}{ Provenience } & Level & Debitage Count \\
\hline IF2 & surface & 1 \\
\hline IF6 & surface & 1 \\
\hline ST 4 & 3 & 1 \\
\hline ST 10 & 4 & 2 \\
\hline ST 14 & surface & 1 \\
\hline ST 15 & 6 & 1 \\
\hline ST 22 & 5 & 1 \\
\hline ST 45 & 1 & 1 \\
\hline ST 66 & 1 & 1 \\
\hline ST 88 & 1 & 1 \\
\hline
\end{tabular}

\section{Results of the Shovel Tests}

A total of 102 shovel tests were excavated within the project area during the course of the pedestrian survey (Figure 4-2). Five shovel tests (ST 59-63) were excavated in the southwest portion of the project area, south of the berm from the Live Oak City Park. An additional 20 shovel tests (ST 72-91) were excavated in the southeast portion of the project area. The remaining 77 shovel tests were excavated along the northern half of the project area on portions that was not disturbed by ongoing construction activities.

Shovel testing was only conducted in areas that were not previously disturbed by construction activities. This was somewhat difficult in the southeast area because portions were already cleared and used for road-ways in the area. The twenty shovel tests in this area were placed along the Salatrillo Creek and the islands of undisturbed areas created by the graded roads. Of the twenty shovel tests, three (STs 80 , 81, and 87) produced fragments of burned rock (Table 4-3) and one (ST 88) produced one piece of debitage (Table 4-2).

In the southwest portion of the project area, five shovel tests were excavated along the transects east of the berm from the Live Oak City Park. Shovel tests were evenly distributed in the area that had not been affected by the creation of the berm. The five shovel tests all encountered similar soils of blocky, dark brown clay. No artifacts were recovered, although Shovel Tests 61 and 62 encountered burned rock fragments in the first level (Table 4-3).

The 77 shovel tests excavated along the northern half of the project encountered a variety of soil layers and terrain. The area adjacent to the Live Oak City Park, though located within the project boundary, was landscaped in places as part of a Frisbee-golf course. Trails led from each hole, and the "greens" were mowed and cleared of brush and trees. Shovel Tests 1 through 14 were excavated in the western portion of this area. Shovel Test 5, located approximately 30 meters northwest of the Live Oak City Park boundary (Figure 4-2), produced a bifacial core (Table 4-1). Additional

Table 4-3. Presence of Burned Rock in the Shovel Tests Excavated During the Survey

\begin{tabular}{|c|c|c|c|c|c|c|c|c|}
\hline ST & Level & Present & ST & Level & Present & ST & Level & Present \\
\hline 4 & 4 & 1 & \multirow{2}{*}{30} & 5 & 1 & \multirow{2}{*}{44} & 1 & 1 \\
\hline \multirow{2}{*}{7} & 3 & 1 & & 6 & 1 & & 4 & 1 \\
\hline & 4 & 1 & \multirow{6}{*}{31} & 1 & 1 & \multirow{2}{*}{45} & 1 & 1 \\
\hline \multirow{4}{*}{10} & 2 & 1 & & 2 & 1 & & 3 & 1 \\
\hline & 3 & 1 & & 3 & 1 & 46 & 1 & 1 \\
\hline & 4 & 1 & & 4 & 1 & \multirow{2}{*}{47} & 1 & 1 \\
\hline & 5 & 1 & & 5 & 1 & & 2 & 1 \\
\hline 11 & 2 & 1 & & 6 & 1 & 49 & 2 & 1 \\
\hline \multirow{3}{*}{15} & 4 & 1 & \multirow{2}{*}{32} & 1 & 1 & \multirow{2}{*}{51} & 1 & 1 \\
\hline & 5 & 1 & & 2 & 1 & & 2 & 1 \\
\hline & 6 & 1 & \multirow{3}{*}{34} & 2 & 1 & \multirow{2}{*}{52} & 1 & 1 \\
\hline 16 & 4 & 1 & & 4 & 1 & & 2 & 1 \\
\hline 17 & 3 & 1 & & 6 & 1 & 53 & 1 & 1 \\
\hline
\end{tabular}


Table 4-3. Continued...

\begin{tabular}{|c|c|c|c|c|c|c|c|c|}
\hline ST & Level & Present & ST & Level & Present & ST & Level & Present \\
\hline \multirow{2}{*}{18} & 2 & 1 & \multirow{5}{*}{36} & 1 & 1 & 61 & 1 & 1 \\
\hline & 3 & 1 & & 2 & 1 & 62 & 1 & 1 \\
\hline \multirow{3}{*}{22} & 1 & 1 & & 3 & 1 & 65 & 1 & 1 \\
\hline & 2 & 1 & & 4 & 1 & \multirow{2}{*}{68} & 1 & 1 \\
\hline & 5 & 1 & & 5 & 1 & & 2 & 1 \\
\hline \multirow{5}{*}{24} & 1 & 1 & \multirow{4}{*}{37} & 1 & 1 & \multirow{4}{*}{69} & 1 & 1 \\
\hline & 2 & 1 & & 2 & 1 & & 2 & 1 \\
\hline & 4 & 1 & & 4 & 1 & & 3 & 1 \\
\hline & 5 & 1 & & 5 & 1 & & 5 & 1 \\
\hline & 6 & 1 & \multirow{2}{*}{38} & 2 & 1 & 80 & 3 & 1 \\
\hline \multirow{4}{*}{26} & 3 & 1 & & 3 & 1 & \multirow{2}{*}{81} & 1 & 1 \\
\hline & 4 & 1 & \multirow{5}{*}{40} & 1 & 1 & & 2 & 1 \\
\hline & 5 & 1 & & 2 & 1 & 87 & 1 & 1 \\
\hline & 6 & 1 & & 3 & 1 & \multirow{2}{*}{92} & 1 & 1 \\
\hline \multirow{2}{*}{27} & 1 & 1 & & 4 & 1 & & 5 & 1 \\
\hline & 2 & 1 & & 5 & 1 & \multirow{2}{*}{94} & 1 & 1 \\
\hline \multirow{4}{*}{29} & 2 & 1 & \multirow{4}{*}{41} & 1 & 1 & & 2 & 1 \\
\hline & 4 & 1 & & 2 & 1 & 95 & 1 & 1 \\
\hline & 5 & 1 & & 3 & 1 & 96 & 1 & 1 \\
\hline & 6 & 1 & & 4 & 1 & 98 & 1 & 1 \\
\hline \multirow{3}{*}{30} & 1 & 1 & \multirow{3}{*}{43} & 2 & 1 & 100 & 1 & 1 \\
\hline & 2 & 1 & & 4 & 1 & 101 & 1 & 1 \\
\hline & 4 & 1 & & 6 & 1 & 102 & 1 & 1 \\
\hline
\end{tabular}

cultural material consisting of debitage was recovered from Shovel Tests 4, 10, and 14, which met the qualifications for a identifying a site. This cluster of positive shovel tests was defined as Field Site 1. Field Site 1 is discussed further in later in the text.

Shovel Tests 15 through 27 were also located in the western portion of the project area. A core was uncovered in Level 1 of Shovel Test 21. A couple fragments of debitage were recovered in other positive shovel tests (STs 15 and 22; Table 4-2), but not in the quantity or proximity needed to warrant further shovel testing or the definition of a site.

Shovel Tests 28 through 35, 38, 39 and 43 were excavated in the north central portion of the project area. While conducting the survey of the transects in this area, a modern trash dump was found along the western branch of the Salatrillo Creek. The dump was located on what had been the Hillmeyer portion of the project area and is not associated with the Kruse farm. Much of the trash was household related and consisted of bed springs, a sink, bottles, broken ceramics, metal cans, and pieces of corrugated metal (Figure 4-3 and Figure 4-4). One section of the trash dump had what appeared to be the remains of a wooden structure that had corrugated metal roof/ sides. Burned rock was encountered in Shovel Tests 29, 32, 34, 38 and 43 (Table 4-3). No prehistoric cultural material was located in this group of shovel tests.

Shovel Tests 44 through 58 were excavated in the most northern portion of the project area. Burned rock was observed in Shovel Tests 44, 47, 49, 51, and 52 (Table 4-3) in the first two levels $(1-20 \mathrm{cmbs})$, though ST 44 produced one small fragment between 30 and $40 \mathrm{cmbs}$. One specimen of debitage was recovered from Level 1 of Shovel Test 45 (Table 4-2). Additional shovel testing was conducted within the vicinity of Shovel Test 45 (STs 92-102) in an effort to determine if additional cultural material was present. Shovel Test 94 produced a retouched flake. Given the number of artifacts recovered and based on their proximity, the locality was defined as Field Site 2. Field Site 2 is discussed in a later section.

During the pedestrian survey of the Hillmeyer portion of the project area, four historic features were noted (Figure 4-3). One feature was a concentration of historic trash (Figure 4-4). Another was a metal building. The third was a cement slab 


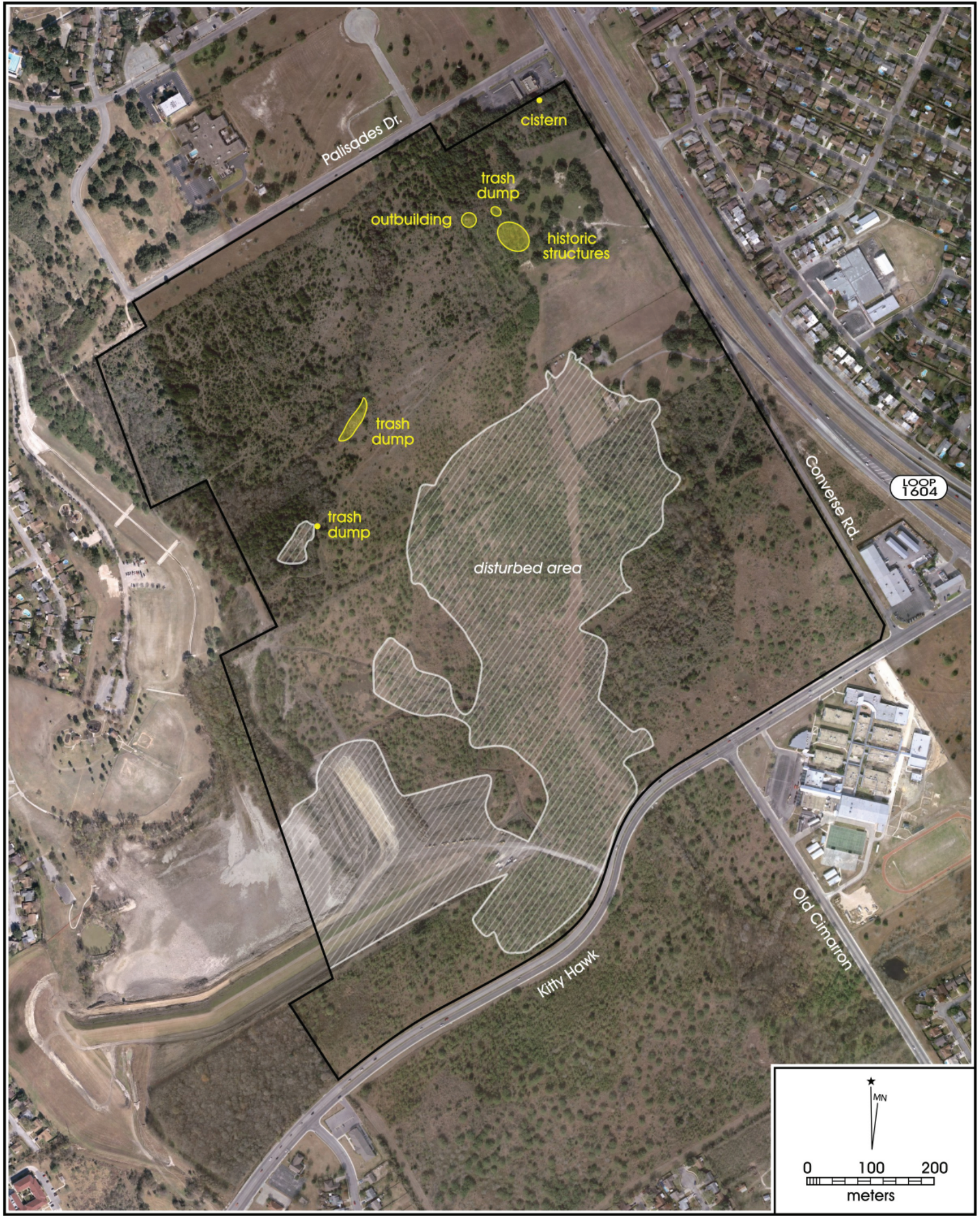

Figure 4-3. Location of historic features within the project area. 


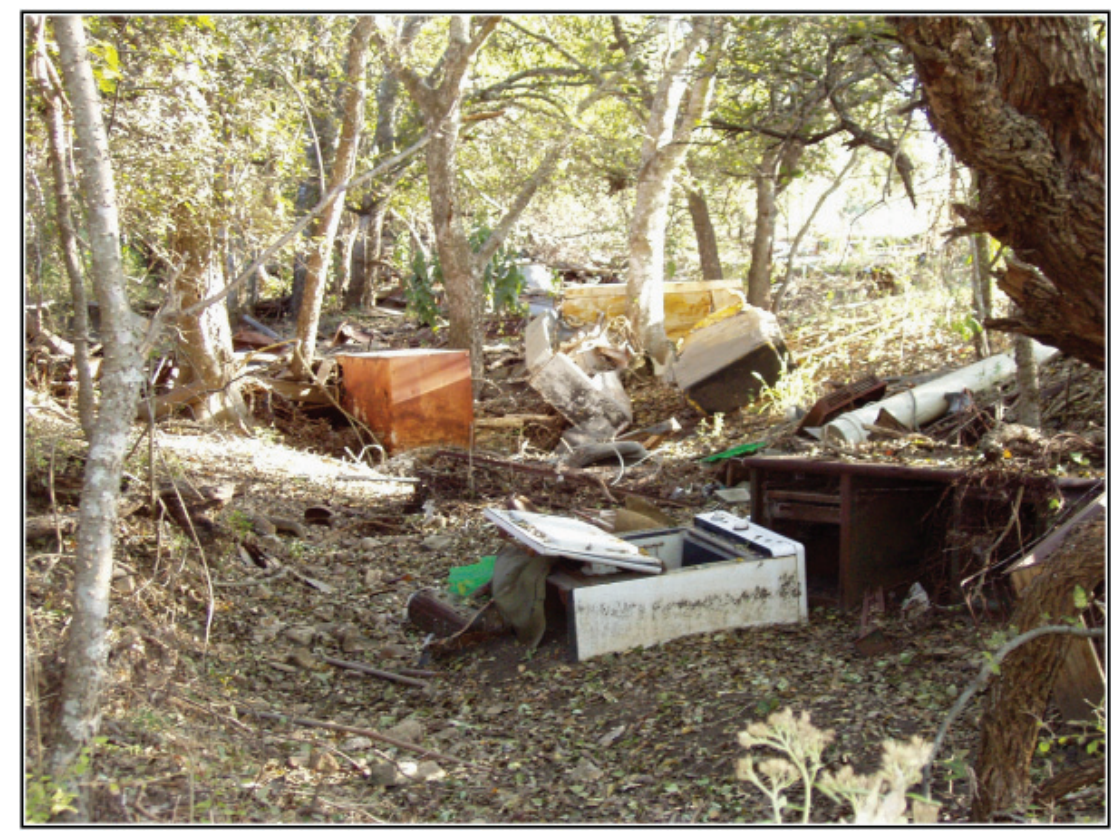

Figure 4-4. Photograph of the trash concentration along western branch of Salatrillo Creek.

that was likely a building foundation. The trash concentration consisted of approximately 20 Texas trailer license plates dating to 1973 , scrap metal fragments, metal can fragments, and glass fragments. This trash concentration was located just north of the metal structure. The metal structure was made of corrugated tin and the roof sloped to one side (Figure 4-5). It appears that the structure was used as a storage building or workshop. Behind the structure is a plow. A cement slab is located to the south of the metal structure. Corrugated metal pieces attached to fragments of a wooden frame, possibly the walls and roof to a structure that once stood on the cement slab, are in the vicinity. The fourth historic feature is a cistern that is located behind the RandolphBrooks Federal Credit Union. The cistern is constructed of concrete and appears to date later than the Hillmeyer occupation of the property.

\section{Site Revisit}

Little is known about site 41BX15. Site records did not indicate the site boundaries nor provide information on its eligibility status. The site was recorded as a lithic scatter. The CAR relocated the site using the UTM information provided on the Texas Site Atlas site form. The site datum was not found during the revisit. A total of ten shovel tests were excavated within the vicinity of the site centroid. From the 10 shovel tests (ST $24,25,26,27,30,31,36,37,40$, and 41), 18 pieces of debitage were recovered (Table 4-4). The four positive shovel tests (STs 31, 36,37 , and 40) produced debitage between Levels 1 and 5 (0-50 cm below surface). The site boundary was recorded as the edges of the landform. Shovel tests excavated at the base of the land form were negative, reaching caliche within the first $20 \mathrm{cmbs}$. Within the vicinity of the site, a low ridge was present that formed a crescent shape. The low portion on the interior of the crescent exhibited signs that water once collected there. Shovel tests on the edge of the crescent exhibited large gravels and relatively little soil. It appears that this feature was a stock pond. The construction of the stock pond looks like it destroyed the site and the materials in the positive shovel tests are in disturbed context. A concentration of historic trash was located along the northern interior edge of the crescent and appears to have been dumped there. The trash consisted of glass Clorox bottles, metal fragments, metal springs, and fragments of other glass containers. Site 41BX15 has no integrity and has been destroyed due to the construction of the stock pond. Therefore the CAR recommends the site as ineligible for inclusion on the National Register of Historic Places (NRHP).

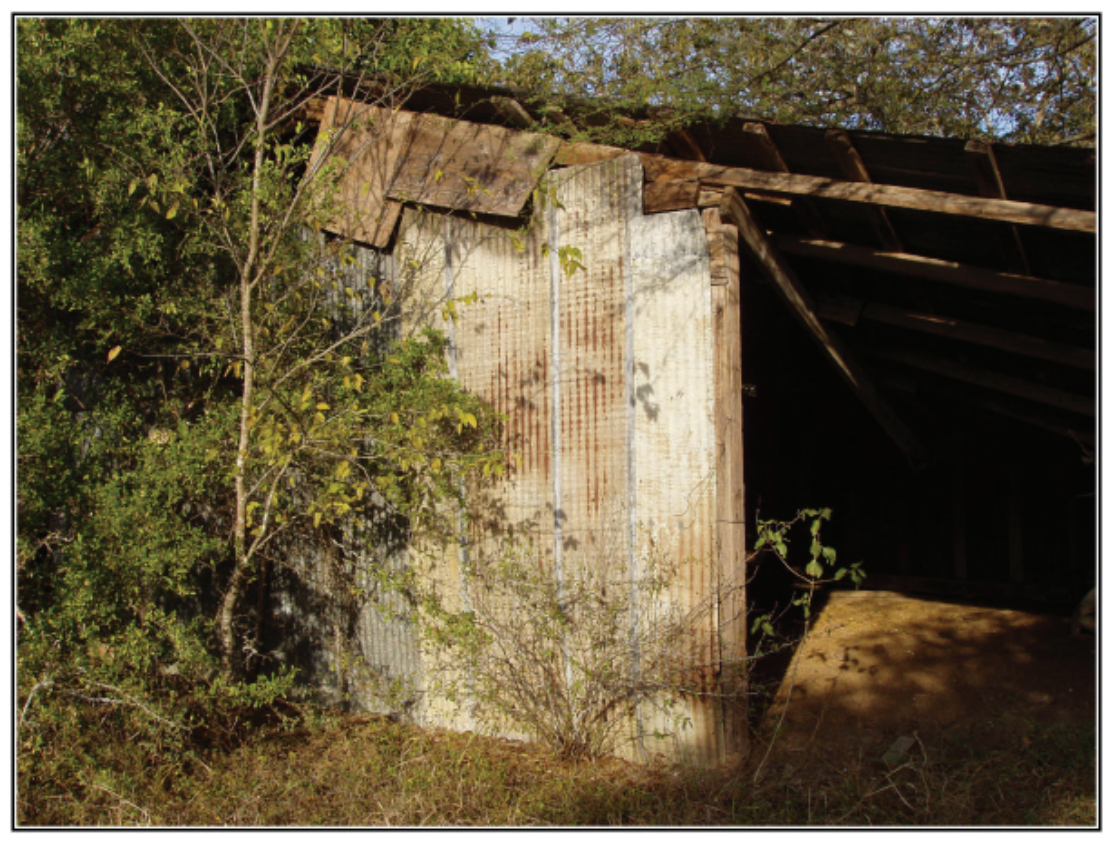

Figure 4-5. Standing metal structure, possibly a cowshed, located in the northwestern portion of the project area. 
Table 4-4. Debitage Recovered from the Shovel Tests During the Revisit of 41BX15

\begin{tabular}{|c|c|c|}
\hline $\mathbf{S T}$ & Level & Debitage Count \\
\hline 31 & 2 & 4 \\
\hline 31 & 3 & 2 \\
\hline 31 & 4 & 1 \\
\hline 31 & 5 & 1 \\
\hline 36 & 2 & 3 \\
\hline 36 & 3 & 1 \\
\hline 37 & 1 & 2 \\
\hline 37 & 2 & 1 \\
\hline 37 & 3 & 1 \\
\hline 40 & 2 & 1 \\
\hline 40 & 4 & 1 \\
\hline
\end{tabular}

\section{BX1758}

Site 41BX1758 is located in the western portion of the project area, adjacent to the Live Oak City Park (Figure 4-6). The site consists of a biface located on the surface and debitage and burned rock extending to a depth of $50 \mathrm{~cm}$ below surface. The site incorporates a portion of the Live Oak City Park's Frisbee Golf Course. The Frisbee Golf tees are concrete pads with an information sign. The "greens" are frequently mowed to allow the players access from the tee to the hole. No temporal diagnostic material was encountered during the shovel testing of the area. Shovel Tests 1 through 14 aided in delineating the site boundary. CAR recommends that the site is not eligible for inclusion on the National Register of Historic Places or formal designation as a State Archeological Landmark. The site lacks research potential due to shallow deposits, lack of cultural features and temporal diagnostic material, and the previous and continuing disturbances from construction and use of the Frisbee Golf Course.

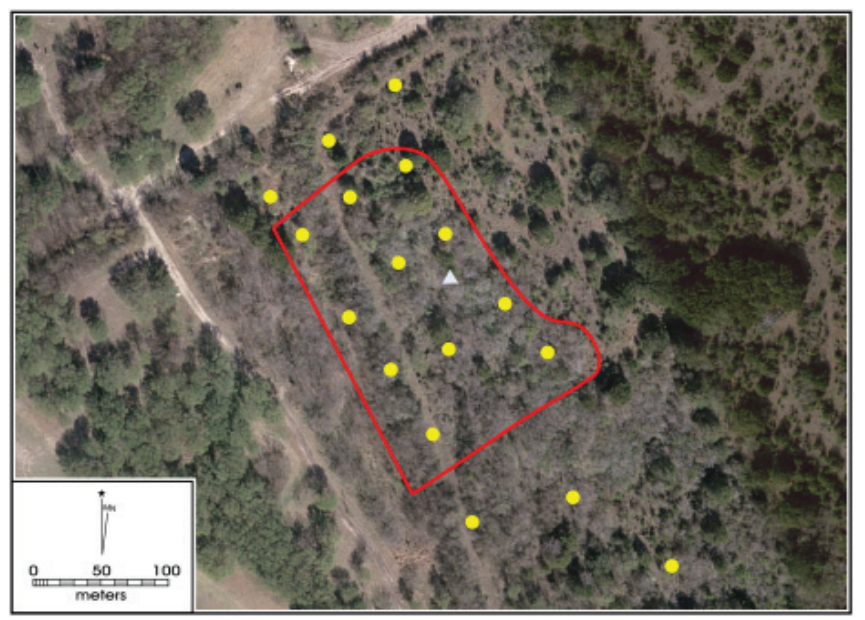

Figure 4-6. Boundary of 41BX1758 showing shovel tests and isolated find.

\section{BX1759}

Additional shovel tests were excavated within the vicinity of Shovel Test 45 to determine if additional cultural material could be located. Shovel Test 45 produced one fragment of debitage and one piece of burned rock in Level 1 and another fragment in Level 3. Shovel Tests 92 through 102 were excavated around Shovel Test 45. Shovel Test 94 produced one retouched flake in Level 1 along with two small fragments of burned rock, one in Level 1 and the other in Level 3. Burned rock was noted in surrounding shovel tests, though only Shovel Test 92, located to the northwest of ST 45 , produced burned rock in lower levels. The remaining shovel tests, excluding ST 93 and 97, produced burned rock only in the first level of excavation. The boundaries of 41BX1759 are defined by the two shovel tests that produced cultural lithic material and the one that produced burned rock at deeper levels (Figure 4-7). A few fragments of chipped stone were noted on the surface within the site boundary. The

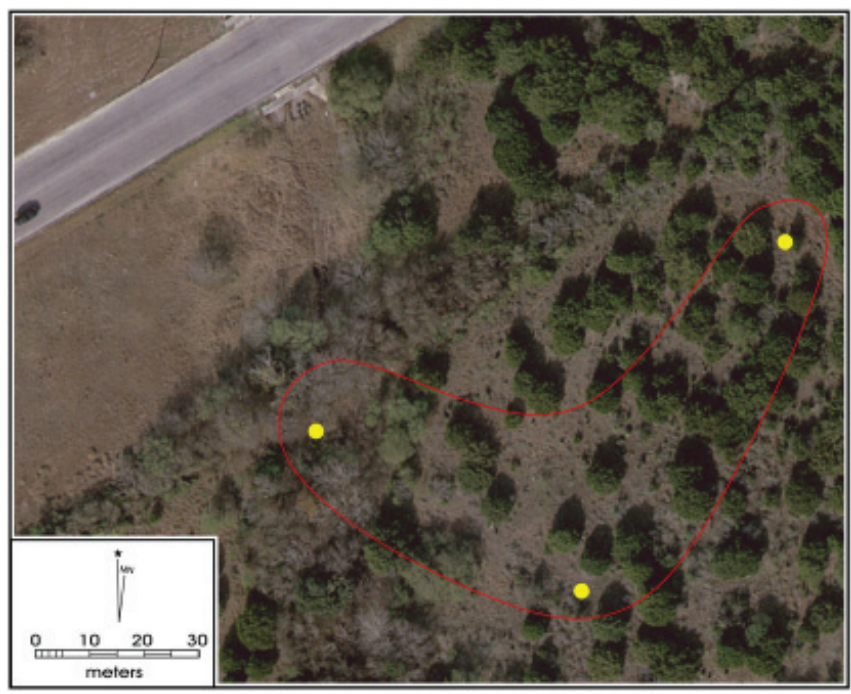

Figure 4-7. Boundary of $41 B X 1759$ showing shovel tests.

CAR recommends that the site is ineligible for listing on the National Register of Historic Places or formal designation as a State Archeological Landmark. The site's research potential is low due to a lack of temporal diagnostic material, the low number of artifacts encountered, the absence of cultural features, and the lack of data types (i.e. faunal remains, charcoal) that may allow significant regional or temporal study. The CAR recommends that no further archaeological investigations occur at the site.

\section{BX1760}

During the reconnaissance of the 173-acre tract disturbed by current construction activities a concentration of historic material was encountered in the vicinity of the Kruse 
farmhouse (Figure 4-8). The historic material consisted of white earthenware ceramics, stonewares, porcelain, vinyl record fragment, glass of various colors (green, olive, blue, milk, aqua, rose, carnival, and cobalt), wire nails, metal knife, hinges, spoon, brick, leather shoe sole, shotgun shell, and bone fragments. Clarence (Clay) Kruse indicated that this area is the location of a cellar that was filled in after his family left the farm in 1947. Near the concentration is a tree that was used for hanging calves and pigs during the slaughtering process (personal communication 2007). Located to the northwest of the historic material concentration was a capped well outlined by the footings for a structure that Clay Kruse identified as their windmill. The historic materials noted pre-dates 1950 and meets the criteria for designation as a historic site. In close proximity to the site (approximately 10 meters), a prehistoric biface was located in a pile of dirt that appeared to have been created by bulldozing activities. The house no longer stands and the cellar had been filled in at an unknown date. The Kruse farmstead at one time consisted of the farmhouse, a barn, a cow pen, hog pen, chicken coop, mule pen and barn, and a garden. The property was used for farming cotton and corn. Due to the disturbed nature of the site from construction activities that occurred prior to the reconnaissance, the CAR

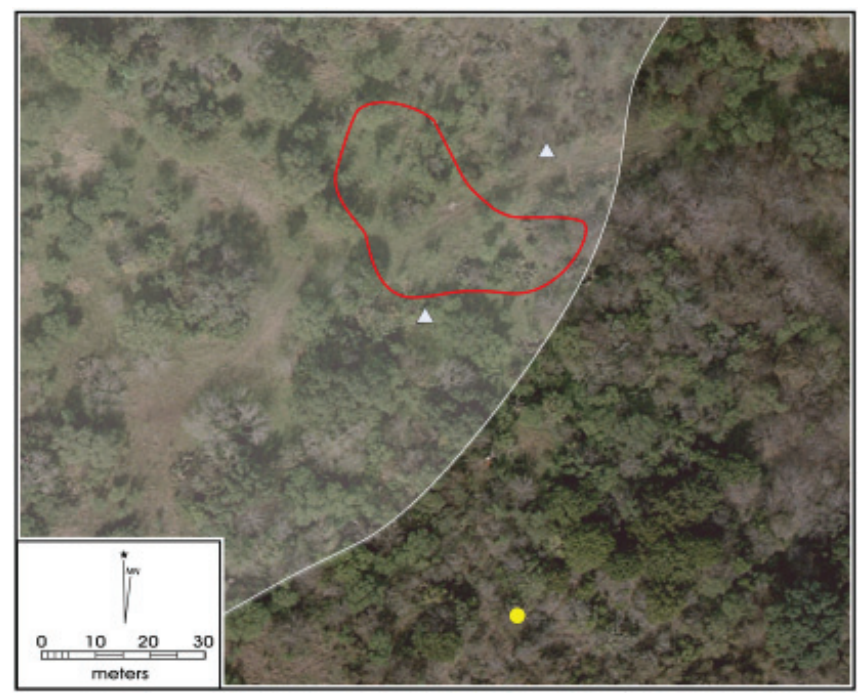

Figure 4-8. Boundary of 41BX1760 showing shovel tests, and isolated finds.

recommends that the site is ineligible for listing on the National Register of Historic Places or formal designation as a State Archeological Landmark. 


\section{Chapter 5: Discussion and Recommendations}

The reconnaissance and pedestrian survey of the 411-acre tract of land designated for the Northeast Alamo Community College Campus was conducted during the month of November, 2007. A segment consisting of approximately 238-acres was walked by a team of archaeologists in an effort to locate significant cultural deposits that were affected by the construction of the community college buildings. The remaining 173-acre portion was subjected to an intensive pedestrian survey to determine if intact cultural deposits existed outside the area of immediate impact. In addition, Site 41BX15 was revisited to gather information as to the condition of the site.

The reconnaissance of the construction impacted areas of the project area produced no diagnostic material or concentrations of significant cultural remains. The area within the vicinity of the Kruse farmhouse and out-buildings did exhibit a scatter of historic material that dated to the late $19^{\text {th }}$ to early $20^{\text {th }}$ Century. Information from the Kruse family reveals that there was a cellar to the farmhouse that was filled in after they sold the property. In addition, the outhouse was located behind the farmhouse, closer to the creek. Reconnaissance did not encounter evidence of the outhouse. Though the historic context of the site proves to be highly interesting, further investigations of the Kruse farmstead were not conducted as it fell within the area disturbed by current construction activities. The historic material concentration which is likely in the area of the Kruse house has been designated site 41BX1760. Due to disturbance from construction activities, no further archaeological investigations are recommended for 41BX1760.

One prehistoric biface was recovered within the vicinity of the Kruse structures but no additional prehistoric material was noted in the area. Clay Kruse remembers collecting one projectile point, approximately two inches in length, from the farm when he was a child. The remaining reconnaissance of the construction impacted areas encountered five more lithic tools, but none were diagnostic and were not in close proximity to one another.

The intensive pedestrian survey was conducted on the 173acre tract that had not been disturbed by the construction activities. This included the excavation of 81 shovel tests spaced throughout the undisturbed areas. The shovel tests did not encounter any diagnostic material or intact significant cultural deposits. Modern occupation of the Hillmeyer portion of the property was evident. One standing structure was noted. The structure was constructed of corrugated metal siding and roof on a wooden frame and dirt floor. The structure may have been utilized as a cowshed. Within the vicinity of the structure was a concentration of trash that produced Texas license plates dating to the 1970s. Additional trash concentrations were located along the creek banks and bed, and the material remained consistent with the modern date. A concrete slab was located in the northwest portion of the property, and corrugated metal siding and remnants of a wooden frame were noted on the ground within the vicinity of the slab. Electrical pole that exhibited porcelain insulators were also found still standing with in the vicinity. Behind the Randolph-Brooks Federal Credit Union, located at the corner of Palisades Road and the access road of Loop 1604, a large cement cistern was located. These structures likely were constructed after the property left the Hillmeyer possession, and appear to post date 1950 .

Site 41BX15 was revisited and a total of 10 shovel tests were excavated radiating out from the site centroid. Four of the shovel tests were positive for cultural material, but no temporal diagnostics were uncovered. CAR recommends that the site does not warrant nomination to the National Register of Historic Places nor formal designation as a State Archeological Landmark.

Two additional sites were documented during the course of the survey. 41BX1758 is a prehistoric site of unknown temporal affiliation. Shovel testing and surface inspection identified a biface, debitage and burned rock. 41BX1759 is a prehistoric site of unknown temporal affiliation with identified cultural materials consisting of a retouched flake, debitage and burned rock. Both sites are recommended as ineligible for inclusion on the National Register of Historic Places due to their lack of research potential.

In summary, the pedestrian survey of the APE and revisit of 41BX15 produced no significant cultural deposits that contain or retain cultural deposits with significant research potential and therefore would require additional investigations. Shovel testing indicated that cultural material did not extend beneath $60 \mathrm{~cm}$ below surface throughout the project area, therefore it was determined that backhoe trenching was not necessary. The CAR recommends that Site $41 \mathrm{BX} 15$ is ineligible for 
listing on the NRHP, and requires no additional research. The three new sites, 41BX1758, 41BX1759, and 41BX1760, are recommended as ineligible as well and require no additional testing. Therefore, CAR recommends no additional archeological investigations within the project area, and we suggest that the proposed construction activities of the Northeast Lakeview Alamo Community College Campus proceed as planned. 


\section{References Cited}

BCDR (Bexar County Deed Records)

http://www.countyclerk.bexar.landata.com/. Accessed December 2007.

Bement, L. C.

1991 The Thunder Valley Burial Cache: Group Investment in a Central Texas Sinkhole Cemetery. Plains Anthropologist 36(135):97-109.

Black, S. L.

1986 The Clemente and Herminia Hinojosa Site, 41JW8: A Toyah Horizon Campsite in Southern Texas. Special Report, No. 18. Center for Archaeological Research, The University of Texas at San Antonio.

1989 Central Texas Plateau Prairie. In From the Gulf Coast to the Rio Grande: Human Adaptations in Central, South and Lower Pecos Texas, by T. R. Hester, S. L. Black, D. G. Steele, B. W. Olive, A. A. Fox, K. J. Reinhard and L. C. Bement, pp. 17-38. Research Series No. 33. Arkansas Archeological Survey, Fayetteville.

Black, S. L. and D. G. Creel

1997 The Central Texas Burned Rock Midden Reconsidered. In Hot Rock Cooking on the Greater Edwards Plateau: Four Burned Rock Midden Sites in West Central Texas, by Steve L. Black, Linda W. Ellis, Darrell G. Creel, and Glenn T. Goode, pp. 269-305. Studies in Archeology 2. Texas Archeological Research Laboratory, The University of Texas at Austin.

Blair, W. F.

1950 The Biotic Provinces of Texas. Texas Journal of Science 2(1): pp. 93-117.

Bousman, B. C.

1998 Paleoenvironmental Change in Central Texas: The Palynological Evidence. Plains Anthropologist 43 (164):201-219

Bousman, B. C., B. W. Baker and A. C. Kerr

2004 Paleoindian Archeology in Texas. In The Prehistory of Texas, edited by Timothy K. Perttula, pp. 15-97. Texas A \& M University Press; College Station.

Chipman, D.

1992 Spanish Texas 1519-1821. University of Texas Press, Austin.

Collins, M. B.

1995 Forty Years of Archaeology in Texas. Bulletin of the Texas Archeological Society 66:361-400.

2004 Archeology in Central Texas. In The Prehistory of Texas, edited by Timothy K. Perttula, pp.101-126. Texas A\&M University Press, College Station.

Collins, M. B., D. B. Hudler, S. L. Black

2003 Pavo Real (41BX52): A Paleoindian and Archaic Camp and Workshop on the Balcones Escarpment, South-Central Texas. Studies in Archeology 41, Texas Archeological Research Laboratory, The University of Texas at Austin. Archeological Studies Program, Report 50, Environmental Affairs Division, Texas Department of Transportation. 
Fentress, C. D.

1986 Wildlife of Bottomlands: Species and Status. In: Bottomland Hardwoods in Texas: Proceedings of an Interagency Workshop on Status and Ecology, May 6-7, 1986, edited by C. A. McMahan and R. G. Frye, pp. 37. (Austin: Texas Parks and Wildlife Department, Wildlife Division, March 1987).

Ferring, C. R.

2001 The Archaeology and Paleoecology of the Aubrey Clovis Site (41DN479) Denton County, Texas. Center for Environmental Archaeology. Department of Geography, University of North Texas.

Fox, A. A., and D. E. Fox

1967 The Classen Rockshelter, 41BX23. Manuscript on file, Center for Archaeological Research, The University of Texas at San Antonio.

Hester, T. R.

1978 Early Human Occupations in South Central and Southwestern Texas: Preliminary Papers on the Baker Cave and St. Mary's Hall Sites. Manuscript on file. Center for Archaeological Research, The University of Texas at San Antonio.

1990 Plainview Artifacts at the St. Mary's Hall Site, South Central Texas. Current Research in the Pleistocene 7:14-17.

1995 The Prehistory of South Texas. Bulletin of the Texas Archeological Society 66:427-459.

2007 St. Mary's Hall Site. The Handbook of Texas Online. http://www.tshaonline.org/handbook/online/articles/SS/bbs1. html. Accessed December 2007.

Highley, C. L., C. Graves, C. Land, and G. Judson

1978 Archeological Investigations at Scorpion Cave (41ME7) Medina County, Texas. Bulletin of the Texas Archeological Society 49:139-194.

Huebner, J. A.

1991 Late Prehistoric Bison Populations in Central and Southern Texas. Plains Anthropologist 36(137):343-358.

Jackson, J.

1986 Los Mesteños: Spanish Ranching in Texas, 1721-1821. Texas A\&M University Press, College Station.

Johnson, L.

1994 The Life and Times of Toyah-Culture Folk: The Buckhollow Encampment Site 41KM16, Kimble County, Texas. Report 38, Office of the State Archeologist, Austin.

Johnson, L. and G. T. Goode

1994 A New Try at Dating and Characterizing Holocene Climates, as well as Archaeological Periods, on the Eastern Edwards Plateau. Bulletin of the Texas Archaeological Society 65:1-51.

Kalter, A. J., R. M. Rogers and M. N. Smith

2005 Analysis and Reporting for 41FY135, the Sandbur Site, Fayette County, Texas. PBS\&J, Document No. 020388. Archeological Studies Program Report No. 73. Texas Department of Transportation, Austin. 
Kruse

2007 Kruse Family History. http://kruse.family.googlepages.com/krusehistory. Accessed November 2007.

Mauldin, R. P., and D. L. Nickels

2001 An Archaeological Survey of Twin Buttes Reservoir, Tom Green County, Texas. Archaeological Survey Report No. 300. Center for Archaeological Research, The University of Texas at San Antonio.

Mauldin, R. P., D. L. Nickels, and C. J. Broehm

2003 Archaeological Testing to Determine the National Register Eligibility Status of 18 Prehistoric Sites on Camp Bowie, Brown County, Texas. Archaeological Rurvey Report No. 334. Center for Archaeological Research, The University of Texas at San Antonio.

Meltzer, D. J. and M. R. Bever

1995 Paleoindians of Texas: An Update on Texas Clovis Fluted Point Survey. Bulletin of the Texas Archaeological Society $66: 47-81$

Nickels, D. L., C. B. Bousman, J. D. Leach, and D. A. Cargill

1998 Test Excavations at the Culebra Creek Site, 41BX126, Bexar County, Texas. Archaeological Survey Report No. 265, Center for Archaeological Research, The University of Texas at San Antonio; Archeology Studies Program, Report 3, Environmental Affairs Division, Texas Department of Transportation, Austin.

Norwine, J.

1995 The Regional Climate of South Texas: Patterns and Trends. In The Changing Climate of Texas:Predictability and Implications for the Future, edited by J. Norwine, J. Giardino, G. North, and J. Valdes, pp. 138-155. Texas A\&M University, College Station.

Our Lady of Perpetual Help (OLPH)

2007 History of Our School. http://olphselma.org/. Accessed December 2007.

Patterson, L. W.

1988 Chronology of Arrow Point Types in South Texas. La Tierra 15(4):29-33.

Prewitt, E. R.

1981 Cultural Chronology in Central Texas. Bulletin of the Texas Archaeological Society 52:65-89.

Powell, J. F. and D. G. Steele

1994 Diet and Health of Paleoindians: An Examination of Early Holocene Human Dental Remains. In Paleonutrition: The Diet and Health of Prehistoric Americans, edited by Kristen D. Sobolik, pp. 176-92. Occasional Paper No. 22. Center for Archaeological Investigations, Southern Illinois University, Carbondale.

Quigg, J. M., C. Lintz, F. M. Oglesby, A. C. Earls, C. D. Frederick, W. N. Trierweiler, D. Owsley, and K. W. Kibler

1993 Historic and Prehistoric Data Recovery at Palo Duro Reservoir, Hansford County, Texas. Technical Report 485. Mariah Associates, Inc., Austin.

Ricklis, R. A.

1995 The Ceramics of the Toyah Horizon and the Rockport Phase as Indicators of some Basic Sociocultural Patterns. Bulletin of Texas Archeological Society 66:195-203. 
Roemer, E. and S. L. Black

1977 Archaeological Survey and Testing at the City of Live Oak Park, Bexar County, Texas. Archaeological Survey Report No. 47. Center for Archaeological Research, The University of Texas at San Antonio.

South Central Texas Regional Water Planning Group (SCTRWPGP)

2006 http://www.watershedexperience.com/ish_vege_areas.html Accessed October 2007.

Southern Regional Climate Center (SRCC)

2006 http://www.srcc.lsu.edu/southernClimate/climatesummaries/ Accessed October 2007.

Steen, R. W.

2007 World War I. The Handbook of Texas Online. http://www.tshaonline.org/handbook/online/articles/WW/qdw1.html. Accessed December 2007.

Taubenberger, J. K. and D. M. Morens

20061918 influenza: the mother of all pandemics. In Emerging Infectious Diseases [serial on the internet]. January 2006, Vol. 12, No. 1. http://www.cdc.gov/ncidod/EID/vol12no01/05-0979.htm\#cit. Accessed December 2007.

Taylor, F. B., R. B. Hailey, and D. L. Richmond

1991 Soil Survey of Bexar County, Texas. U.S. Department of Agriculture Soil Conservation Service. The Soil Conservation Service, Washington, D.C.

THC (Texas Historical Commission)

2007 The Texas Archeological Site Atlas. http://nueces.thc.state.tx.us/. Accessed December 2007.

Toomey, R. S., M. D. Blum, and S. Valastro, Jr.

1993 Late Quaternary Climates and Environments of the Edwards Plateau, Texas. Global and Planetary Change 7:299320.

Turner, S. E. and T. R. Hester

1993 A Field Guide to Stone Artifacts of Texas Indians. Gulf Pub. Co., Houston, Texas.

Weir, F. A.

1976 The Central Texas Archaic. Unpublished Ph.D. dissertation in Anthropology, Washington State University, Pullman.

Winkler, B. A.

1982 Wild Plant Foods of the Desert Gatherers of West Texas, New Mexico and Northern Mexico: Some Nutritional Values. Unpublished Master's thesis, Department of Anthropology, The University of Texas at Austin. 